Portland State University

PDXScholar

Fall 1-8-2014

\title{
Being Human: How Four Animals Forever Changed the Way We Live, What We Believe, and Who We Think We Are
}

Jocelyn Mary Brady

Portland State University

Follow this and additional works at: https://pdxscholar.library.pdx.edu/open_access_etds

Part of the Animal Studies Commons, and the Creative Writing Commons Let us know how access to this document benefits you.

Recommended Citation

Brady, Jocelyn Mary, "Being Human: How Four Animals Forever Changed the Way We Live, What We Believe, and Who We Think We Are" (2014). Dissertations and Theses. Paper 1531.

https://doi.org/10.15760/etd.1530

This Thesis is brought to you for free and open access. It has been accepted for inclusion in Dissertations and Theses by an authorized administrator of PDXScholar. Please contact us if we can make this document more accessible: pdxscholar@pdx.edu. 
Being Human: How Four Animals Forever Changed The Way We Live, What We Believe, And Who We Think We Are

\author{
by \\ Jocelyn Mary Brady
}

A thesis submitted in partial fulfillment of the requirements for the degree of

\author{
Master of Fine Arts \\ in \\ Creative Writing
}

Thesis Committee:

Michael McGregor, Chair

Paul Collins

Dan DeWeese

Portland State University

2013 
(C) 2013 Jocelyn Mary Brady 


\begin{abstract}
Our lives would not be what they are today without animals. From the food we eat, to the clothes we wear, animals provide tangible evidence of their importance every day. But more than that, animals have shaped who we are and what we believe. Often in ways we don't see.

That's what inspired me to write Being Human. This work began as an examination of how humans have altered animals to better match our imaginations and ideals, and too, the way these animals have irrecoverably altered how we live and look at the world. Consider, for example, that before they became physically useful to us in providing meat or skills or companionship, animals were central figures in our stories, mythologies, and religions. All the while, of course, these animals remained both ignorant and at the mercy of whatever we imagined - or needed - them to be.
\end{abstract}

And what does all of this say about us? What can we learn about ourselves from looking at animals, and more specifically, looking at the way we treat them? In a society where animal flesh comes to us freshly packed and cleanly saran-wrapped, and pets are treated as members of our families, we tend to look at animals as one thing or another. A farm pig is not a companion animal, any more than a cat is a meal-in-waiting. At least not in our culture. We generally see what's convenient or desirable and when things get messy or complicated, we tend to look away. In so doing, we miss the opportunity to clearly see who 
we really are, what we're capable of, and what, if anything, we might want to change as a result.

I chose four specific animals that show us different sides of ourselves. These beings are both familiar and strange, part of our everyday lives but often only found on the periphery. Each animal symbolizes one of four categories: food, pest, worker and pet. And each connects to a human need: pigs with consumption, pigeons with communication, horses with control and cats with companionship. They are arranged in this order to reflect the deepening complexity of their respective human needs-from the simplest, the need to eat, to the most complex, the need for companionship. (Arguably, control can be considered the most complex, however I chose companionship as the culminating need because it inherently involves all of the other three.)

I hope if I accomplish only one thing, it is this: after reading, you see these animals - and your relationship to them - a little bit differently than before. 


\section{Table of Contents}

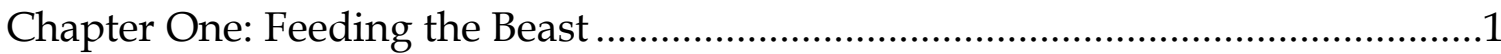

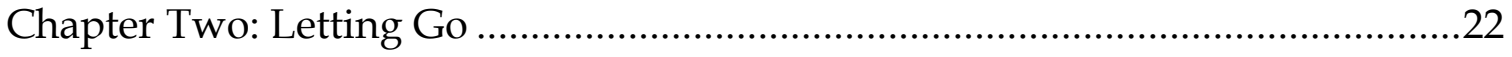

Chapter Three: (Losing) Control ........................................................................41

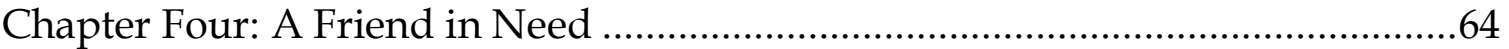

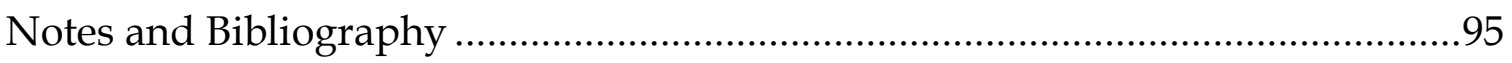


Chapter One: Feeding the Beast

The creatures outside looked from pig to man, and from man to pig, and from pig to man again; but already it was impossible to say which was which.

- George Orwell, Animal Farm

Today's entertainment is taking place near the banks of Oregon's Willamette River, on the Oaks Amusement Park fairgrounds established more than a century ago. There are maybe 75 of us, mostly young kids with their parents, packed around a 150-foot, semicircular race track topped with pine chips that gleam beneath a cloudless May sky. As we wait, I pick up the clean scent of pine mixing with that of kettle corn and corndogs and I wonder: will anyone here wind up eating the contestants we're about to see?

Then the stars of our show, four All Alaskan Racing Pigs, appear behind their gates, beneath a banner that says "YOU NEVER SAUSAGE A SHOW." As the piglets stand there, bobbing their little heads in anticipation (I assume) of the race, the kids in the crowd start to coo and squeal and point and say things like “Look mommy, piggy!” and the moms nod and smile and all is honkey-freaking dory. As if everyone here only sees how cute these animals are while completely ignoring the fact the piglets will grow up to get their throats slit and their bodies hacked apart and-you see those adorable little piglet potbellies? - become delicious pieces of bacon. Just saying. 
In the center of the semicircular track, separated from the running lanes by stubby white fencing, is a young dark-haired man wearing blue jeans, a gray sweater, and a headset. Donald, our host. He raises his arms up bit by bit, like a winged corkscrew, and says, slowly, dramatically, "three," then, "two," and, after a deep breath and with great gusto, "one!" as he swoops his arms back down. The gates burst open and out rush the four piglets, running as if their lives depended on completing this race.

The scene is absurd and adorable and surprising. Like most baby animals, piglets are delightful to watch and, thanks to their anatomy, appear to have giant, permanent smiles etched across their faces. Piglets also resemble puppies when they run, with floppy ears bouncing as the animals bound toward the finish line - at a remarkably quick pace to boot. Unlike creatures we've artificially selected over time to compete in this manner, such as Thoroughbred horses with their bevy of fast-twitch muscle fibers, pigs have been bred for 10,000 years only to be eaten-and outward appearances suggest as much. But pigs are faster than they look, clocking in at speeds of up to 20 miles per hour.

As the traveling racing troupe's founder, Bart Noll, told me over the phone before the show, “They're amazingly quick. Usually people don't think of pigs as athletic, but all mammals have an athleticism of some kind that has kept them alive." 
This athleticism is on vivid display as, within seconds, racer Natalie Porkman (you can tell by her magenta vest) edges past Strawberry (orange vest) to take the lead, but as they round the horse-shoe-shaped bend, Sourdough Jack (green) comes up from last place, passing Kobuk (blue), then Porkman, then Strawberry -all within a few breaths and just in time to snag first place. The crowd roars. Children giggle. Donald, who's actually Noll's son, announces the winner: Everyone give a round of applause to Sourdough Jack!

Winning is pointless, of course. No matter the outcome of these races, all of the All Alaskan Racing Pigs will go back into the farming system from whence they came. Noll summarized it this way: "Our philosophy is pigs are food animals. We divert them from the food production chain, make stars out of them, and then they go back to the food production chain."

And that food production chain is what brings me here today. I've always been strangely fascinated by pigs - and why we eat them - even though I've never been around the animals much nor interested in consuming them. To me, pig meat always tasted the way I imagine sweaty gym socks might, which is probably a genetic flaw or advantage, depending on how you look at it. Scientists recently discovered a gene called OR7D4 that's responsible for this kind of pork-eating aversion. According to the study, people who inherit both copies of OR7D4 from their parents perceive the taste of androstenone, a steroid found in both humans and pigs, as "urine-like ... pungent and sour." 1 
Sounds about right. (Thanks Mom and Dad!)

I'm also conflicted about eating animals in general, despite the fact I still consume fish and eggs and cheese and indulged in a turkey I'd personally stuffed and cooked a few Thanksgivings ago. Mostly, I'm uncomfortable even thinking about an animal being uncomfortable, so I generally shun eating meat to avoid feeling responsible. Thing is, even if I decided against eating all animals, including foods made from animal ovaries and mammary glands, and even if I stopped using products made from animal skins, such as leather shoes and belts and the wallet I've had for nearly a decade, I'd still be complicit in a society that uses animals in a host of unexpectedly pervasive ways. Especially the one animal I never wanted to eat.

Here's what I mean: meat aside, pig parts are found in at least 185 consumer products, most of which are probably in your home right now. You know that iconic Crayola crayon smell? That's thanks to porcine fatty acids. The luxuriant, pearlescent quality of conditioner? Yep, pig fat. (Sometimes pig placentas.) Pig cells and bone remnants are also found in inkjet paper (a gelatin layer prevents bleeding), lollipops, protein bars, tiramisu, toothpaste, vitamin gel caps, matchstick heads and face cream. Some beer relies on porcine collagen as a clarifying agent, to remove tannins. Pig bristles (the hair) are used to make hairbrushes and paintbrushes and also provide an amino acid called L-cysteine that bread manufacturers use to soften dough. ${ }^{2}$ 
Pig parts are everywhere. Despite that, we probably don't see pigs around very often - at least not while they're alive. Due to an industrial farming system that has, in the last few decades, moved pigs mostly indoors, you don't really see the animals that make so much possible. And why is that, exactly? Money, for one: keeping pigs confined makes them easier to control, and thus more costeffective. As Dave Warner, spokesman for the National Pork Producers Council in Washington, D.C., told the Chicago Tribune in 2010, "We have found the most efficient way to meet consumer demand for a high-quality, relatively inexpensive product. We're the lowest-cost producer in the world, which is why we're the No. 1 pork exporter in the world." ${ }^{3}$

This exportation business brings in more than $\$ 5$ billion in revenues each year, in exchange for the more than 1.75 metric tons of pork we ship to Canada, Mexico, Japan and China. ${ }^{4}$ At home, the average American eats roughly 40 pounds of pork flesh per year, ${ }^{5}$ which doesn't account for the cosmetics and beverages and other non-flesh items made from pigs. To satiate demand, our system collectively kills roughly 100 million pigs annually. ${ }^{6}$ Average that out and you have 190 pigs slaughtered every minute.

That's a lot of animals, and bigger operations are naturally more capable of handling the feeding and killing of all these pigs than a small farmer. Plus, small farms can't compete with the purchasing power of large ones, which can secure 30 percent discounts on grains or other food supplies and produce 10 
times as many pigs in the same timeframe. While the small operations struggle, the large ones grow bigger and more productive. The more efficient and business-like we become, the worse life gets for the animals. And the more we have to hide.

Watching the All Alaskan Racing Pigs put me close to the animals we rarely see, but to understand what their lives are really like, I had to go inside, where they go.

Wapinitia Farms is situated off an unpaved, sneeze-and-you-miss-it road that skews north from Oregon's Highway 216. A vast expanse of soft white wheat stretches east beyond the sole convenience store within 30 miles. To the west, wide desert sky is interrupted only by the distant snow-capped mass of Mount Hood. The closest town, Maupin, is busiest during these summer months when white water rafting down the nearby Deschutes River is in high season. But only about 460 people call Maupin home year-round. And Claude Williamson knows just about every one of them.

For the past 30 years, Williamson and his wife Emilie have been running Wapinitia Farms, a small hog operation that rears and sells about 200 pigs per season. Some of the town's citizens have worked on the farm, such as the neighborhood girl whose skilled and slender hands implemented the farm's castration efforts for a time. (Male piglets have itty bitty parts that, as Williams 
attests, small, steady hands are better equipped to remove.) Other people might come by to purchase a pig they'll slaughter and prepare at home-BBQ pork is a hot item this August. But the bulk of the pigs raised here get transported about 200 miles west by truck to the Pacific foothills, to Carlton Farms, where they are killed to provide the "100 percent natural" pork-du-jour menu options for the Northwest's finest restaurants and catering companies.

Today, a scorching August Saturday, I arrive prepared to see some of what Williamson has described: several dozen pigs in various stages of the pigto-pork production process. Williamson isn't USDA inspected, one of the provisions for slaughtering and selling pigs for public consumption. Instead, he raises sows (adult female pigs), breeds them mostly through artificial insemination, and raises their young until these offspring reach close to slaughter weight - which is roughly 250 pounds. At that point, per his agreements with Carlton Farms, Williamson will load the pigs onto trucks and the animals will spend their last hour, or so, listening to a rumbling engine before it finally stops, and the pigs are unloaded at the slaughterhouse.

Because the cost of feed is his single biggest expense, Williamson offsets some of this by growing and processing his own grain out of his 150 sprawling acres of soft white wheat. There is also the matter of managing the pigs' waste, which is funneled into a 1,000-gallon cement holding tank he calls the "lagoon." 
On this day the light wind has switched its standard southwest route to gust due south. Which is why, when I step out of my car onto Williamson's gravel driveway, the lagoon's sour stench greets me.

“Welcome!" Williamson bellows as he emerges from his modest yet ostensibly roomy two-story house. His gleaming hazel eyes and remarkable posture make it nearly impossible to believe he's 78 years old.

Williamson's wife pops out through the front door to wave hello, her sunny demeanor matching the cloudless desert sky. The unfortunately-timed waft of sewage causes her waving palm to turn sideways as if to sweep the offending odor away from her nose.

"It's usually not like this," Ellie says as she squints and shifts her gaze from me to Williamson.

"Those southern winds." He shakes his head.

I'm suddenly embarrassed but not sure if it's for Williamson and Emilie or for myself. I know very little about pig farms - about farms in general - and Williamson kindly accepted my self-imposed invitation to view this place after pressing him for details over the phone. We had talked about the lagoon, but I don't think any of us expected me to smell its presence within the first few minutes of my visit. Rather than take the opportunity to inquire further, I attempt to change the subject.

“Well I appreciate you having me here," I say, smiling nervously. 
Williamson grins and leads me from his porch to the dusty driveway, as I mull over our last conversation in which he explained that you have to have a permit to store liquid waste in Oregon, and you have to be able to detail how you handle that waste - the materials, size, location, and output of nitrogen. A pig can produce 12 pounds of excrement per day. Williamson has about 130 pigs currently, collectively pooping 1,500 pounds daily. That's 10,000 pounds per week; nearly 285 tons a year. Multiply that by 10, and you have the potential output of a Confined Animal Feeding Operation, or CAFO, such as those owned by the likes of Smithfield Foods or Cargill - two of the four largest pork producers in America, where nearly 70 percent of pig flesh comes from. ${ }^{7}$

Humans have been raising pigs for some 10,000 years and it's only in the last 50 that the practice moved out of public view. Though attitudes skewed negative long before that. Step back to nineteenth century America, and we have the New York mayor stating: “Our wives and daughters cannot walk abroad through the streets of the city without encountering the most disgusting spectacles of these animals indulging in the propensities of nature." This was followed by pig roundups in 1818, $1825,1826,1830$, and 1832, as well as new ordinances that made it impossible to openly own pigs in Manhattan. ${ }^{8}$ (Also in Manhattan: During the 1600s, a long solid wall was built to block semi-wild pigs from rampaging further up the island. This area is now known as Wall Street. ${ }^{9}$ And - hey, coincidence? - sometimes the people 
who work there are derisively called "greedy pigs.") Families eventually stopped raising their own pigs for food and resorted to purchasing pig parts from their local butchers and, eventually, grocery stores. Perceptions of pigs as slovenly beasts persist in America to this day.

Still, as late as the 1960s, pigs were treated like, well, pigs. They'd root around outdoors, dig up insects and fungi, take mud baths to cool down and avert sunburns. Small, family-run pig farms totaled roughly 450,000 so you wouldn't have to go far to see a hog, if you were looking. ${ }^{10}$ No one could have guessed that $\$ 3,000$ and a high school teacher were about to change everything.

Shortly after Wendell Murphy took out a loan to open a feed mill in North Carolina, he realized a few hogs could help him clean up leftovers such as cornhusks. And their manure would prove a handy fertilizer. So he built a pen, bought some pigs, and quietly, irrevocably, altered the trajectory of pig farming. The practice began centering around feedlots, pigs moved from outdoor pens to indoor operations, and business productivity soon took the place of pride. Murphy's company eventually grew into the largest operation in America and is now a part of Smithfield, the largest hog producer in the world. ${ }^{11}$

Today, there are roughly 70,000 family-run hog operations remaining. ${ }^{12}$ Small farms have been replaced by the mega-farms of Iowa and Nebraska. Where a large farm of yesteryear raised maybe 1,000 hogs annually, today's 
CAFOs can handle 15,000. We can process more meat, faster, but that also means we create a lot more waste in concentrated areas. In "Boss Hog," a Rolling Stone article published in 2007, writer Jeff Teitz relays such an account:

A worker who was repairing a lagoon in Michigan was overcome by the fumes and fell in. His fifteen-year-old nephew dived in to save him but was overcome, the worker's cousin went in tosave the teenager but was overcome, the worker's older brother dived in to save them but was overcome, and then the worker's father dived in. They all died in pig shit. ${ }^{13}$

That's obviously not a picture the pork industry wants us to see when we think about eating these animals. Likewise, Smithfield foods-implicated in Teitz' article - responded by saying the work was "filled with misrepresentations and untruths about pork production" and "one of the worst examples of irresponsible journalism that we have seen in a long, long time."14

Presumably to curb this "irresponsible journalism," Iowa recently criminalized undercover video investigations of factory farms. ${ }^{15}$ This happened shortly after animal rights groups released disturbing footage of egregious abusepiglets being tossed around by their ears and slammed into walls; adults with prolapsed rectums (extruding intestines) that were left to decay and turn black and stink; weak and ill babies thrown upon one another in wheelbarrow-sized tubs until enough accumulated to justify gassing them to death. Similar so-called "ag gag" bills banning undercover films are cropping up around the country which, understandably, fuels activists' argument that there must be something terrible to hide. 
Maybe such acts of violence in huge hog farm operations are rare. Or maybe most people don't understand what it takes to raise and fatten and kill farm hogs at the rate required to meet demand. Somehow, some way, humans in such environments must adapt to the massive scale of slaughter surrounding them every single day. Cruelty may be unacceptable to all parties, but we might not all agree on its definition.

Williamson leads me to a large pen resembling a greenhouse. Half-covered, half exposed to the elements, the pen houses about two dozen boisterous pigs that are currently snorting and mingling in the mud. I look at the pigs and they glance back at me through the simple wooden fence dividing us. I think of how people used to do this all the time: look at pigs. It used to be normal for us to see, in plain view, the animals we routinely eat-a dichotomy most of us don't really deal with in this country anymore.

"These are females," Williamson says as he adjusts his faded navy blue baseball cap. These lady hogs are free to roam here between pregnancies, and during pregnancy, basically right up until they give birth and start weaning in the nearby farrowing room. Unlike larger pig farms, these females aren't placed in gestation crates, which are 7-foot long by 2 -foot wide metal enclosures that prevent pregnant females from moving around too much, or from fighting each other and potentially harming unborn fetuses. The U.S. National Pork Council 
posits that such enclosures are necessary to "provide well-being to the sows," but animal welfare advocates disagree. Temple Grandin, for example, who applies her unique blend of sensitivities and pragmatism to changing the way large farms raise and slaughter animals, suggests these crates are like "asking a sow to live in an airline seat." 16 In a pseudo-victory for animal activists (and, arguably, the pigs) McDonald's announced in 2012 that it "believes gestation stalls are not a sustainable production system for the future" and "wants to see the end" of gestation crates in our food system. ${ }^{17}$

"You want to see the babies?" Williamson asks, a smile spreading across his youthful face.

“Sure!" I reply.

The first time I saw a piglet, it was dead, and smelled like a cross between foot fungus and nail polish remover. This was in my high school biology class, ninth or tenth grade. I remember staring at the tiny creature on my lab table, feeling both disgusted and enthusiastic about the task at hand; the animal lover in me protested while my inner science nerd couldn't wait to see what a heart and liver and lungs looked and felt like. (I was especially interested in cutting open the skull and probing the brain, which was not a required part of the assignment.) As I sliced through the pale pink flesh, pulled out long, wormy cords of intestines, and stared at shiny organs that once kept this pig alive, I thought 
about the pictures I'd seen in human anatomy books. We look so much alike inside.

I'd later discover just how alike pigs and people are. Aside from the obvious differences (elbows, knees, opposable thumbs), pigs have so much in common with us (digestive system, relative organ size, the way blood circulates - and even an above average use of the neocortex, the part of the brain that reasons) that they're routinely used for a number of lab experiments, such as crash test dummies and ammunition and body armor testing for the U.S. ${ }^{18}$ military. Diabetes patients relied exclusively on pig insulin until Genentech made a human derivative in $1978 .{ }^{19}$ Porcine hides have been used as temporary skin substitutes. And pig hearts - or at least parts of them-are currently used in people with failing heart valves. In fact scientists in Japan think we can take this a step further - they're right now creating human-pig hybrid creatures, called chimeras, that grow human organs for transplant. ${ }^{20}$

The similarities don't end there. Like us, pigs are naturally social and hierarchical; regardless of gender, pigs will fight to determine who carries the status of top hog. They are omnivorous opportunists; when given the choice, they are more likely to choose sweets over vegetables. They seem to love flopping around in the sun despite their propensity to burn and blister. They see in color. They snuggle. And they dream. 
They're also stubborn (ahem, pig-headed), and destructive (small populations can tear up hundreds of acres of soil within days). They're susceptible to disease, go crazy in confined spaces, and kill off native animals and plants at rabid rates. And as numerous scientists, farmers, and animal activities point out, they are remarkably intelligent-perhaps too smart for their own good, or maybe, for ours.

Williamson's farrowing room is a big, barn-like structure that's a mix of metal and straw inside, where about a dozen mother pigs wean their offspring. Upon entering we're greeted with the unmistakable high-pitched squeals of dozens of piglets. While he doesn't invest in gestation crates - and in fact advertises the fact his pigs are free to roam in the mud - Williamson believes in the practicality of farrowing stalls. The two enclosures differ in purpose and design; farrowing crates are slightly wider than those made for gestation, and the sides are comprised of sixteen slots between metal bars where baby pigs can access mama's teats. This is again surrounded by bars with slimmer spaces between them, to prevent the babies from wandering off.

“We separate babies from mothers like this so the young don't get crushed," Williamson says flatly. "A 500-lb sow can plop down and not even know she's crushing her baby." 
During one early morning sweep through this room - before he had these crates in place-he discovered five dead piglets. They'd all suffocated under the girth of their mothers.

"There's about a 25 percent mortality rate from crushing," he says. Before my visit, I'd investigated the matter by interviewing animal science professor Ken Kephart. He corroborated these findings, referencing several studies that show gestation and farrowing crates indeed reduce mortality rates of the young. Yet some studies find no statistical variation in mortalities. And if a pig were free to roam, as it would have been 50 years ago, would this death-bycrushing really be such a big problem?

In any case, it doesn't look to me to be the most comfortable space in the world for a sow to breastfeed. And judging by the way Williamson describes the oinky resistance of the mothers when they're introduced to their new [10]-week farrowing abode, I don't suspect the pigs appreciate the setup. But I've never raised hogs. I've never had to pick up five dead babies who had been squeezed out of existence by an oblivious mother. To Williamson, farrowing crates are helping him keep his pigs - and his business - alive.

I stand here watching the piglets totter around their enclosure, nipping at each other in a race to find mother's milk, and seeing the mothers, some upright and slurping at their food troughs while others lay on their sides and gaze at the exposed ceiling rafters as they let their babies suckle at their warm breasts 
between the crate's cold metal poles. This feels like the intersection of nature and industry. A place where production is king.

And that's what the business of raising animals for human consumption brings us to: a mechanized place where animals are processed as units of production, rather than sentient beings. Though some may argue we don't really know whether pigs are sentient, we can at least view an animal and see when it prefers one thing over the other - sunlight, say, to a tiny metal crate in a dark and smelly room.

Each sow is expected to produce 10 piglets per pregnancy, or 20 annually. If she doesn't perform, she's ousted from the system. Which means she is likely to become sausage. I ask Williamson if he ever gets attached to these pigs.

"Way back in the early days it was easy to get attached," he admits. "I had this one sow who was a truly pathetic creature-her confirmation was terrible. But I kept her around a long time. She'd have 11 or 12 babies at a time." Sometimes, he says, he notices a cute personality. And the neighborhood girl who used to help castrate pigs would get sidetracked for this very reason. “She'd say, 'Oh Williamson look at this one, it's so cute. Look at the color. Can I take it home?'” Williamson recounts. "I would say 'C'mon, we have work to do; it's not going to live! And no, you can't take it home because your mother would kill me.'"

Instead, Williamson focuses on making sure his pigs are healthy. 
Piglets, like human babies, are physically fragile creatures that are highly susceptible to disease. And in close quarters, one sick pig can wreak havoc on the whole herd. Which is precisely why farmers treat the pigs with antibiotics.

"Of course I treat them with antibiotics," Williamson replies when I prod. The subject came up originally when we were chatting about his relationship with Carlton Farms, which positions itself as the natural choice for premium pork (on its website, it claims "Our quality standards mandate that every hog we process is antibiotic-free when it arrives from our growers' farms.") But as Williamson indicates, natural is a vacuous industry term and he doesn't know of any hog farmers who stay in business without the aid of antibiotics.

"Naturally raised? I'm not sure what that means," he states. "People might claim they don't put antibiotics in their feed, but they might put it in their water."

According to one USDA study, antibiotics were given to grower/finisher pigs in 88.5 percent of sites surveyed, which accounted for 96 percent of all grower/finisher pigs. ${ }^{21}$ This "therapeutic" usage of antibiotics is completely acceptable to the industry, although consumers and health organizations are growing increasingly concerned that this practice contributes to the rise of drugresistant bacteria, viruses, and diseases that spread to humans (think H1N1, aka the swine flu). 
Add to this predicament that "natural" is not a federally-regulated term, and you have a marketing advantage in using "natural" to sell products raised or laden with antibiotics or pesticides.

So, when asked if his pigs are naturally raised, Williamson says "I just tell [buyers] that my pigs can run around and be in the sun. Some people care about that and some people don't."

And those that do care to purchase "natural" or "antibiotic-free" pork may change their minds when hit with a price tag.

“They find out what it costs and all of a sudden they don't want to pay that."

Still, there's a growing market for meat that's been raised humanely, for animals that are supposedly raised on healthy whole meals and have the advantage of romping in open fields. Even if "natural" can be used indiscriminately, the label has a strong appeal. In a study of 1,006 consumers, conducted by Shelton Group, twice as many surveyed perceived "100 percent natural" to be the eco-friendly choice over "100 percent organic," despite welldefined certification standards around organic labeling. ${ }^{22}$ For as long as this perception continues, companies like Carlton Farms will be able to leverage "natural's" mass appeal.

Williamson sells an average of 12 pigs per week; in that span of time, Carlton Farms processes roughly 1,000. Since Wapinitia Farms is one of two 
roughly same-sized operations in Oregon that meet Carlton Farm's nebulous requirements for "naturally-raised" hogs, the processing center-according to Williamson - transports most of its pigs in from Montana. (Even "local" is a relative term.)

As we continue through the farrowing room, I continue asking questions about the babies, whether he castrates them under anesthesia (he doesn't), and how fast they grow (pigs reach 225 pounds in five months). Some of the piglets here are positively skeletal but apparently even these will, ahem, pork up fairly quickly. Once they're finished weaning at eight weeks, they'll be shuffled into the "finishing" room, which is where we're headed next.

The term "finishing" is something of a misnomer. "Fattening" room would be more accurate. The innards of this barn are teeming with adolescent pigs that are fed at regular intervals to reach their market weight. These youngsters have the luxury of bustling around on concrete floors strewn with fresh hay, but despite the slats in the sideboards and Williamson's daily room cleaning, this room is thick with the smell of ammonia. I don't know how the pigs can smell their meals over the stench. I try not to gag, but my eyes start watering and I'm having a hard time concentrating on Williamson's detailed rundown of what and how often these pigs eat. Is this why we don't want to see-or smell - pigs in our neighborhood? Have we locked them out of sight so 
we don't have to deal with the fact they eat and shit and make noise? My head starts to spin. I'm not sure what to think.

With great relief we exit the finishing room and I gulp in the hot air. Williamson leads me to a picket fence overlooking the wheat, and the manure lagoon glistening 100 yards in the distance. He leans on the fence and gazes out at the horizon. We get to talking about the neighborhood kids, the one who's supposed to finish painting his house a fire-engine red, the former castration girl who's flirting with a local boy who's considering attending college across the country. Small-town life continues, for now, here in Maupin, but Williamson doesn't know what will happen to his farm when he retires.

"My wife says we'll be able to retire in 6 years ... We'll be 84, " he muses. He recalls speaking to a fellow pig farmer a few years ago who was entering these golden years, and thinking that guy would be crazy not to retire and do something - anything - else. But the man said he wouldn't know what to do with himself if he retired, and today Williamson shares the sentiment.

"Now that I'm that guy's age, well, I don't care to do anything else," Williamson says softly. "My three kids don't want anything to do with this business. So when I'm gone, I'm not sure what will happen to this land. They'll probably sell it." 


\title{
Chapter Two: Letting Go
}

\begin{abstract}
A pigeon. The kind of soul that didn't impede on anyone; just walked around worrying about its own business, trying to get through life without pulling everyone else down. With its own needs and selfish habits. Brave. A communicator. Intelligent.

Beautiful. Soft-spoken. A creature that mates for life.

Unattainable until she has a reason to trust you.
\end{abstract}

- Jamie McGuire, Walking Disaster

One sunny day in high school an injured pigeon landed in the middle of our grassy quad. It was recess break - right after lunch - and a crowd of maybe 100 teenagers started to form. You could tell the bird was in bad shape when it tried to fly away but instead flapped only one operable wing while the other, now a useless mass of gray feathers, hung flaccid. How did this happen? Maybe a hawk's claws sliced through the pigeon's wing in mid-flight. Maybe some dumb kid shot a pellet gun at the animal. Nobody seemed to know. And, for a few moments, nobody did a thing. I stood there with the crowd, soaking up the scene, curious but unsure, wondering what to do. Should I go out there, pick it up, and take it ... where, exactly? I felt stupid not knowing what I'd do so I opted to do nothing at all.

Relief came when I saw the handsome, popular boy - this dark-haired and dark-eyed mystery I'd never worked up the courage to talk to-approach the pigeon. He stared at the bird as he strutted toward it in his surf-brand T-shirt and khaki shorts and Vans sneakers, never looking up to see how the crowd was 
reacting. Brave, I remember thinking, having the guts to stand out there like that, for everyone to see and talk about and judge. But what did I know? We were all just kids then, teenagers with unclear ideas of who we were and what difference we could - or wanted - to make in the world. The boy cocked his head to the side as if pondering what to do next. And we all just stood and watched, waiting for something to happen.

Jadia Ward never thought she'd be releasing pigeons for a living. White ones, specifically. And I certainly never thought I'd be standing here with her, holding this dainty white heart-shaped birdcage in front of a couple dozen people mourning the loss of a woman I had never met. But here we are, outside the Milwaukie Lutheran Church on a slightly overcast Thursday afternoon in August. Everyone is looking in our direction but no one makes eye contact. I'm grateful. This situation is uncomfortable.

The priest says a few words and, as we agreed before the attendees joined us out here, he nods at Ward, two feet to his left, and me, two feet to his right. Time to release the birds - the three Ward has, symbolizing the Holy Trinity, followed by my bird, who's here to represent the dead woman's spirit ascending to heaven. Ward opens her cage and the three birds take flight, circling around a bit - to orient themselves - and head north, back to Ward's loft. Pigeons like these always fly home. 
That's my cue. But, because she thought it would just be perfect, Ward, just as the service ended in the church, recruited a little blond girl to stand next to me and open the cage. So, I stoop down a little and the little girl opens the lid, tentatively. And then ... nothing happens. The damn animal won't budge. I reach my hand into the cage and, while attempting to scoop my hand under the creature to urge its departure, the bird shits on my fingers. And then, as if satisfied with this little message, it takes flight.

"Well, she was feisty!" says Jadia Ward to the crowd. Ward's referencing the dead woman, Ms. Olivia, ${ }^{i}$ and what the pastor said about her just a few moments ago - if there's one word I can think of to describe Ms. Olivia's spirit, that word is feisty. I see Ms. Olivia's daughter, Rebecca ${ }^{\text {ii }}$ (who incidentally sang “Wind Beneath My Wings" on a pre-recorded CD played during the service; I'm pretty sure I was the only one who delighted in the coincidental link between that song and my being here to assist in dove-releasing) - smile and wipe away a tear with her crumpled tissue.

We're all here today because Ms. Olivia recently passed after complications with ovarian cancer, a disease known by some as the "silent killer" because it's extremely difficult to detect, until it's basically too late to effectively treat. Ward told me that's also how her grandmother died and that ovarian

\footnotetext{
${ }^{\mathrm{i}}$ Not her real name.

ii Also a pseudonym.
} 
cancer truly is a silent killer because no one knows you're sick until you're already dying. I'd never heard any of this about ovarian cancer before. Ward says that's because people only focus on the things they can see-breast cancer gets all the attention, the marches and celebrity fundraising, because people (but especially men, according to Ward) want to save the most obvious of sexual appendages. People like to save what they think is beautiful, and what they desire most. Or something like that.

This is all news to me, and I'm not really sure I agree. But it gets me thinking about why I came here in the first place: to learn about pigeons in relation to human communication. To see more than what meets the eye and, perhaps, shine a light on what seems a part of our past-who we are - that we've either taken for granted or, by and large, forgotten.

People have been releasing doves for more than four thousand years to commemorate special occasions. To the Egyptians, doves symbolized peace and prosperity for newlyweds. Greeks and Romans associated doves with Aphrodite and Venus, the goddesses of love. In China, doves warded off evil spirits. And doves still represent the divine spirit in Christianity. ${ }^{1}$ Also: soap.

But here's the thing: these doves, the Rock Dove, aka Columbia livia, is a pigeon. The same bird we see out in the streets, rummaging through garbage or pooping all over our buildings and sidewalks and cars. The only difference? 
Color. We know how color has shaped our perception, and consequently, our actions, in the past. Judging other living beings based on what they look like alone isn't exactly our most admirable trait. But we still do it. And today, the white version of a bird we otherwise ignore or identify as a pest is still considered beautiful.

Though pigeons of all colors used to be incredibly useful. As writer Andrew Blechman describes them, pigeons were humanity's original FedEx. ${ }^{2}$ Before cars, wireless networks, cell phones, even telegraphs, pigeons were our fastest means of communication with people in the next city (or few) over. Traveling at speeds averaging 50 miles an hour, over distances up to 1,000 miles long, pigeons could outpace messages sent by horseback and cross bodies of water faster than we could by boat. Pigeons were also a better alternative to people literally running messages hither and thither. Such as sprinting 26.2 miles from Marathon to Athens so you can tell everyone the Greeks beat the Persians on the battlefield, and promptly dropping dead. Here's looking at you Pheidippides (and seriously anyone who runs that far, ever), who, as legend has it, yelled "victory!" before a crowd of Athenians and dramatically collapsed to the ground, thus setting the precedent for celebrating the end of your marathon run. (Except of course the dropping dead part.)

Up until the telegraph, pigeons dominated our long-distance communication. We had to keep messages short; whatever we wrote had to fit on 
the tiny paper rolled and stuffed into little pigeon leg canisters (the ones used during WWI and WWII were about the size of a pen cap) or handmade pigeon backpacks tied or clamped onto the animals. And nothing too heavy - one bird in Brazil had 40g of marijuana on its back and struggled to fly, which is how the prison guard caught the animal and realized a group of prisoners had trained the pigeons to deliver drugs (and sometimes mobile phones) to the prison. ${ }^{3}$

Pigeons, 200 of them in fact, were instrumental in helping Paul Julius Reuter deliver stock news between Aachen and Brussels until 1851, when Reuter opted for the brand new telegraph cable to transmit info in mere seconds. ${ }^{4}$ According to the Reuters news website, the pigeons basically helped Reuter "establish an enviable reputation for speed, accuracy, integrity and impartiality." 5 Thanks to a solid start on the backs of pigeons, Reuter opened more branches, became very popular, and pretty much became one of the world's most successful news publications of all time.

Ward never expected she'd be releasing doves for a living but always loved animals - in fact wanted to be a veterinarian while in college, only to discover her 3.98 GPA wasn't high enough to get her into a good vet school. She worked odd jobs for a while instead, and wound up becoming a freelance marketing specialist-slash-graphic designer. Then, one day, a dove landed on her porch and changed everything. 
It was September 12, 2009, the day after her father died. Sometime around nine a.m., Ward discovered the animal sitting there, looking at her through the sliding glass doors. "This is too weird," she thought. Her paternal grandmother had always loved doves, and Ward herself had dreamed of having a flock of white doves released at her wedding with husband Mike, though the two went without the birds when they married 25 years ago.

"So I went outside and gave the bird some water," she told me. "And I left to go arrange my father's funeral, thinking the dove would be gone by the time I got back." But hours later, the dove was still there. Feeling sentimental, and in honor of her father who'd taught her how to play the guitar, Ward decided to go outside and play a couple of tunes for the bird. The creature seemed intrigued, moved in closer and cocked its head as she sang. After a time, Ward can't remember exactly how long, she decided to sever ties.

"Enough," she told it. "You've stayed long enough. Time for you to go." And just like that, she said, the dove departed.

But for Ward, this signified the beginning of something new. Over the following weeks, Ward and her husband connected with a dove owner in Arizona to learn about the business of raising doves and releasing them at special events - weddings and funerals, mostly, symbolizing beginnings and endings. 
In August of 2010, she placed an order for 30 doves and never looked back. "I may have never become a veterinarian, but I take care of these birds like a vet would. I'm their personal care physician," she half-jokes when telling me this in her van on the way to the funeral. Her big, blond curls obscure most of her face as she watches the road. She gives me a glance, thin lips stretched into an impish grin.

I'm not sure what to think of Ward. She's warm and welcoming and tells the best stories. But that's the thing: I don't know if I believe everything she says. And yet, I let her stories stand between us without question. Like this one: when Ward and her husband Mike decided to remarry on their $25^{\text {th }}$ anniversary, with a dove release this time, it seemed as though her father's and sister's spirits came back around to put on a show. Through the birds, of course. The Wards invited a small group, maybe a couple dozen friends, to their expansive backyard near an old airport hangar in Vancouver, Washington. They started by releasing the doves that represented departed members of their family. Mike's "mother" was first, and "she" flew into the sky as any normal dove would. Then came Jadia's sister, who had died several years ago after getting hit by a car on a busy street. The bird representing Jadia's sister flew into Jadia Ward's window before making it up onto the roof.

"Well, she was always a little slow," Ward told the wedding guests. The dove then flapped its way up to the roof and sat there, staring at the assembly. 
Next came Ward's father incarnate, who, instead of flying, hopped out of the cage and stood right by Ward's side.

"He always wanted to give me away," Ward joked to the audience. Everyone laughed. The sun beamed. Ward reminded me, upon the telling, that she and Mike had eloped a few months after they met-so no one from the family was there when they originally wed. Papa Bird, after fulfilling his wish, flew up to meet Sister Bird on the roof.

"My father never could leave a good party early!" Ward continued. The crowd roared. And finally, after the ceremony, the "I do's," the reception, Papa Bird and Sister Bird flew off together into the blue.

It all seemed to good to be true, but like I said, I just let the stories stand the way Ward described them. Whether or not this is how any of it really happened, I believe this is the way Ward remembers it.

Of all the stories about pigeons saving human lives, the one I remember most clearly is that of Cher Ami, who made it back to her loft headquarters despite losing an eye, being shot in the breast, and nearly losing her left leg (which dangled by a bloody tendon when she finally landed). German troops shot down every pigeon, including Cher Ami on that October day in 1918, but only Cher Ami was able to get back into flight and transmit the message. The note-We are along the road parallel to 276.4. Our own artillery is dropping a barrage directly on us. 
For heaven's sake, stop it-made it to the U.S. Army Signal Corps and helped save 500 men who might have otherwise been killed by friendly fire. Cher Ami, who retired after sending this twelfth and final message of her career, became a mascot for the Department of Service and was awarded the Croix d guerre, a French military decoration awarded to Allied troops for gallantry. ${ }^{6}$

All in all, pigeons received 32 Dickin Medals for their wartime service - a bronze medallion specially created to honor animals in service. (The award also went to 18 dogs, three horses and one cat named Simon who survived Communist gunfire and subsequently helped eradicate a scourge of rats from the HMS Amethyst Naval ship.) ${ }^{7}$ One award - for a pigeon named Commando who earned his recognition after making 90 successful missions - was auctioned off in 2004 for more than 9,000 British pounds. ${ }^{8}$ Clearly these medals still mean something to someone out there, even if the animals that earned the awards never had a clue.

By the 1950s, communication had advanced so much that pigeons were no longer a wartime necessity. Messages could be transmitted securely over the wire. The U.S. Army officially ended the Signal Pigeon Corps in 1957, forty years after the service began. ${ }^{9}$ Some of the pigeons were donated to zoos, others were auctioned to the public. A rather unceremonious end to a service-and the animals - that saved thousands of soldiers. 
Pigeons are completely out of commission today, except for in China, where 10,000 pigeons are kept in case of communication breakdown caused bywho knows? - some solar flare or a kid in his basement who hacks into every source of electromagnetic power, leaving all the world disconnected from broadcast, mobile, Internet. ${ }^{10}$ It's good to have pigeons in such predicaments.

Once instrumental, pigeons are now largely useless to most of us. Sometimes pigeons are even considered a nuisance, which is why the pest industry exists. Trafalgar Square used to be infamous for huge population of pigeons, but all the excrement made it less appealing and the city started placing metal spikes on the rooftops to discourage pigeons from perching on buildings.

Though it's really our fault pigeons wants to perch on our buildings at all. When we started breeding them, for food initially, and then for sharing or symbolizing what we wanted to say, we brought pigeons away from their natural seaside cliff settlements and into our manmade ones (statues, city parks and skyscrapers). It's difficult to pinpoint precisely how and when this happened; even the Cornell Lab of Ornithology states, "The birds have such a long history with humans that it's impossible to tell where the species' original range was."

At any rate, we made our world more attractive to pigeons than their natural one, with all our scraps and garbage aggregates. We invited them in to 
fulfill our needs without an exit strategy for the day we decided pigeons were no longer useful. But the pigeons see this as a long-term deal. These are animals that mate for life, after all; wired to stick through thick and thin with their companions. Did we even see that when we first looked at pigeons? Did we ever stop to consider how life would change for the animal we decided best served our needs?

Probably not. Though we can maybe take some solace in the fact scientists are starting to figure out what goes on in a pigeon's brain. Starting with how pigeons find their way around - and how (if not why) they always return home. This "homing" ability is why pigeons became so useful in the first place. Aside from the original use we found in eating pigeon flesh, of course. (I've heard a few friends say squab is absolutely delightful. Tastes like chicken, but better. Did these friends know squabs were baby pigeons? Not all of them. One friend in particular was appalled and vowed to never eat squab again although her opinion on the baby flesh deliciousness did not change.)

Anyway, for as long as we exploited the birds for their homing ability, people didn't really know how the homing ability worked. Kind of incredible, isn't it? We know about Pluto and black holes-how things we've never physically seen (and probably never will) function - but can't put our finger on an animal we've been interacting with for thousands of years. Not like we didn't try; theories on pigeon homing abounded over the years, including the most 
dominant one that pigeons basically navigated by using the earth's magnetic fields and an extraordinary sense of sight and smell. ${ }^{11}$ Some scientists now believe that pigeons actually create acoustic mental maps with low frequency infrared sound waves. Geologist John Hagstrum helped fashion the theory when he noticed that pigeons couldn't accurately find their way home when disturbed by the sonic boom of Concord jets flying nearby. ${ }^{12}$

We also know that pigeons are much more intelligent (or self-aware, at any rate) than they might seem. Using a "mirror test," scientists are able to tell whether beings are self-aware. These beings-including both animals and children - are tested by seeing how they react when shown video recordings or mirror images of themselves. Here's an example: a red dot is placed on a pigeon's belly and the pigeon is placed in front of a mirror. If the pigeon starts investigating its own body, rather than poking at the reflection, then the pigeon is self-aware. ${ }^{13}$

There aren't a whole lot of animals that "pass" this mirror test. Threeyear-old children have a hard time with it and, in this respect, can't compete with a pigeons' cognitive ability. ${ }^{14}$ Same applies to all great apes; only the adults are able to recognize themselves. Other animals with this prescience include bottlenose dolphins, killer whales and elephants. (Cats, the one creature that seems most self-aware, if you ask me, do not trust the imposter in the mirror and therefore fail our little test.) 
Most of us are oblivious to all this. I mean, do YOU sit around reading pigeon studies? These findings just aren't sexy enough to make the news. So, by and large, we miss out on all the wonderful little nuances of pigeon behaviorhow both mom and dad take care of the babies, for example; how both parents have the ability to make this special kind of milk for their offspring that no other creature can produce; how mom and dad stay together until death do they part. And how pigeons did so much to help us thrive. Will we ever appreciate these animals for what they contributed, or for, simply, what they are? Or will it take some kind of tragedy - extinction, say - for us to realize what we've had, and lost?

It's happened before. And the first animal to have ever been officially documented to go extinct the moment it happened was a kind of pigeon. The Passenger Pigeon. These birds traveled around in search of food, from north to south and back, unlike Rock Doves which prefer to settle in one location. Passenger Pigeons were also probably the most numerous animal in the Western hemisphere, numbering up to five billion and found in flocks stretching a mile wide and 300 miles long. ${ }^{15}$ The Passenger Pigeon made the sky go black from morning to night. 
Can you imagine the sight? John Muir describes the scene in his autobiography:

\begin{abstract}
Of all God's feathered people that sailed the Wisconsin sky, no other bird seemed to us so wonderful. The beautiful wanderers flew like the winds in flocks of millions from climate to climate in accord with the weather, finding their food-acorns, beechnuts, pine-nuts, cranberries, strawberries, huckleberries, juniper berries, hackberries, buckwheat, rice, wheat, oats, corn-in fields and forests thousands of miles apart. I have seen flocks streaming south in the fall so large that they were flowing over from horizon to horizon in an almost continuous stream all day long, at the rate of forty or fifty miles an hour, like a mighty river in the sky, widening, contracting, descending like falls and cataracts, and rising suddenly here and there in huge ragged masses like high-splashing spray. How wonderful the distances they flew in a day-in a year-in a lifetime! 16
\end{abstract}

Not everyone felt the love. Farmers, after settling in the Americas, would see their crops decimated by the birds. An 1858 Detroit Free Press article states: "Wild pigeons sweep the late planted cornfields clean, pulling up the stalks and devouring every grain. ... They cannot be driven away for when fired at they only rise to light again within a few rods."17

Some people just figured pigeons made for good eating, and since there were so many of the birds, there was probably a lot of money to be made in selling the animals. So for a few decades, peaking in the 1870s, Passenger Pigeons were killed en masse, 500 or 600 of their bodies packed into barrels, and sold to eager buyers across the country. During peak season, up to 400,000 Passenger Pigeons would be killed in one week. James Audubon captured the nineteenth century scene: 
Everything was ready, and all eyes were gazing on the clear sky which appeared in glimpses amidst the tall trees. Suddenly there burst forth a general cry of "Here they come!" The noise which they made, though yet distant, reminded me of a hard gale at sea passing through the rigging. ... Thousands were soon knocked down by the pole men. The birds continued to pour in. The fires were lighted and a magnificent as well as wonderful and almost terrifying sight presented itself. The pigeons, arriving by the thousands, alighted everywhere, one above another until solid masses as large as hogsheads were formed on the branches all around. Here and there perches gave way under the weight with a crash, and, falling to the ground, destroyed hundreds of birds beneath, forcing down the dense groups with which every stick was loaded. It was a scene of uproar and confusion. I found it quite useless to speak, or even to shout to those persons who were nearest to me. Even the reports of the guns were seldom heard, and I was made aware of the firing only by seeing the shooters reloading. ${ }^{18}$

Clearly none of this boded well for an animal that laid only one egg a year and provided no other noticeable service to humanity; Passenger Pigeons did not help humans transport messages. Plus, these birds basically stopped mating when forced to live in smaller and smaller groups. So, seen only as a commodity, the fate of the Passenger Pigeon did not end well, though it did end swiftly. In 1900, the last wild specimen was shot and killed by a teenage boy in Pike County, Ohio. ${ }^{19}$ But there was still hope in three birds still alive at the Cincinnati Zoo.

Martha, the last living female Passenger Pigeon, was 15 years old when the last wild specimen was killed in 1900. She lived with two other males but after years of trying, none of the zoo workers could get Martha and one of the fellows to breed. Too slim of pickings for Martha. The zookeepers and general 
public, realizing what was happening - a species was about to go extinct-went on a futile campaign to find Martha a mate. More and more people came to see Martha and the American Ornithologists' Union offered \$1,200, then $\$ 3,000$ to anyone who could find even one Passenger Pigeon. The zoo upped the ante to $\$ 15,000$. To no avail; at 1 p.m. on September 1, 1914, Martha was found lying on the bottom of her cage. She was 29 years old. ${ }^{20}$

Today all you can see is a stuffed effigy of the animal. I remember standing at the Field Museum in Chicago, staring at the delicate, dead-eyed creature I'd never see in real life. Even then she, or he, looked frightened. Her slender neck stretched from a sky blue body with black-tipped wings and a burst of rust-orange plumage on her chest. She was beautiful to my eyes. But no one really stopped for long to regard the Passenger Pigeon; there were much more exotic animals to see, such as the man-eating lions of Africa and the signature attraction: Sue the T-Rex.

Author and ecologist Aldo Leopold, who was alive when the Passenger Pigeon ruled and when it ultimately disappeared, described what we've lost in his 1949 book A Sand County Almanac:

The pigeon was a biological storm. He was the lightning that played between two opposing potentials of intolerable intensity: the fat of the land and the oxygen of the air. Yearly the feathered tempest roared up, down and across the continent, sucking up the laden fruits of forest and prairie, burning them in a traveling blast of life. ${ }^{21}$ 
I don't know if Columba livia will go down like the Passenger Pigeon. It's doubtful; our street pigeons are survivors who've adapted to humanity's way of life. But, aside from the pigeons people care for as novelty racing birds or release doves, it's kind of depressing what happens to animals we hold little regard for. Poison, traps, abuse. We don't see pigeons as pets or even food animals; they are pests that defecate on our buildings and cars. At best, invisible. At worst, reviled.

He must have been angry. The popular boy. I missed that before. But that's how it looked to me as I watched him approach the pigeon on our grassy, high school quad and, instead of stooping down to help the injured bird, the boy reared his left leg back as if he were about to strike a soccer ball. Amidst the whoops and hollers of his friends egging him on - the kid kicked the creature as hard as he could. It could have been any animal, I suppose, but I think if it had been a dog or cat or some other creature we culturally adore, someone would have stopped what happened. Instead, all of us - me and a group of other teenagers - stood around and watched as the boy kicked and kicked the pigeon, over and over and over. Every time it tried to fly, the boy kicked again. Harder. Again. Every strike killing the animal along with the spirits of every one of us who cared but were too afraid or unwilling to make it stop. 
Finally, the animal just collapsed in defeat. I watched the bird's little body inflate and collapse, laboriously, as it gasped for a few last breaths. Inhale, exhale. Inhale, exhale ... Gone. 


\title{
Chapter Three: (Losing) Control
}

\begin{abstract}
Of all the dumb brutes the horse is the one which deserves the most gratitude of man. It has been his docile and willing servant for ages.... The day of the horse, say the prophets, is well nighdone. In another generation or two he will gave way to a soulless machine ... Let him go-but let us not forget him. Time was when there were no devil wagons or gasoline engines, no locomotives or steam thrashers - and in that time man and horse, laboring valiantly side by side, conquered continents and made the waste places bloom.
\end{abstract}

-New York Times, 1909

The first time Madison tried to hug Bruston he shuddered and hightailed it to the opposite wall, nervous as all hell. Madison, a pretty 18-year-old blonde from McMinneville, Oregon (population 33,000), took this as a sign that the relationship could take a while to blossom. But there was a scholarship on the line and Bruston's future at stake and only 98 days to do what now seemed the impossible: tame this 10-month-old wild mustang. And then give him away.

Madison is not alone. She's one of 22 teenagers participating in the 2013

Teens and Oregon Mustangs program, an extension of both the Bureau of Land Management's "Adopt a Living Legend" initiative and the Mustang Heritage Foundation - all of which aim to facilitate successful wild horse adoptions. In the Teens and Oregon Mustangs program, youth have just over three months to transform a wild yearling that has probably never seen a human before into a tame animal that will eventually let a hominid climb onto its back (the same way 
a hungry predator would). The teens then show their mustangs on day 98, walking them around a corral, past plastic animals and over a 6-inch tall bridge with a 6-inch gap of fake water (aluminum foil) - the kinds of things that signify danger and thus spook baby mustangs in the wild. All this culminates in an auction where, with any luck, all of the horses find what animal shelters like to call "their forever home."

Madison heard about the program at a county fair she attended last summer - "You work with wild baby horses? What freaks!" she remembers saying to the young girls showing their newly tamed mustangs during one of the fair's events. Madison had never spent much time around horses and didn't know the basics, such as how to lift a horse's legs to inspect and clean its hooves. But she wanted to learn. She'd always loved horses - or the idea of them, at any rate.

Talk to any young girl about horses, and you'll undoubtedly see the horseysparkle in her eyes. I mean, I don't have any facts to support this, but I know I'm not the only one who faithfully, hopefully wrote 'pony' on my Christmas wish list every single year, until I realized the animal, like Santa himself, would never show up. Instead I took consolation in miniature plastic versions - My Little Pony or Western Fun Barbie's Sun Runner, a beautiful blonde horse with great hair (also blond), equipped with an assortment of pink and blue ribbons. 
Thinking about it now, it seems model horses are to little girls what model cars are to young boys: mini icons of an as-of-yet dimly conceived power.

My guess is most girls in America have a pretty clear image of horses before they ever meet the animal in the flesh. Horses to my five-to-twelve-yearold self were fascinating, mythical creatures that must have, long ago, greeted princesses in magical sparkly forests with glistening brooks and winding paths leading to majestic castles where nothing truly bad ever really happened. Horses gave stature to knights, prestige to kings, and wildness (let's just say it: virility) to princes. Horses gave meaning to words like awesome. But, did you notice? Women almost never rode or controlled the animals; horses were the exclusive province of men. Unless of course you were a damsel thrown onto a horse by a heroic prince, or a warrior woman belonging to the legendary Amazon tribe (a matriarchal group which, as Greek myth has it, were the first soldiers to fight on horseback and often chopped off one of their breasts in order to master the bow and arrow).

These stories fueled my ideas of what a horse was, and what it meant. The true and fictional depictions fed and blurred into one another-ranging from men fighting real wars on horseback to characters such as Atreyu from the Neverending Story, who was tasked with saving - you got it - the princess of Fantasia, and valiantly began his mission atop his trusted horse, Artax. (Artax later drowned in the Swamps of Sadness, which was traumatizing as a child 
though I later realized the death was a plot device to rid the hero of his past and set him on his solo journey to save the world.)

Horses are-or have historically been - tethered to men and notions of masculinity. Warriors. Knights. Cowboys. Think of the language we still use to quantify engine power (horsepower) or to describe a strapping and spirited young man (stallion). Even "chivalry" descends from the French word for horse, cheval. And consider that up until the late $19^{\text {th }}$ century, it wasn't really normal for women to ride horses. Females were generally expected to ride in the impractical "side-saddle" position rather than straddle, or ride "astride," a horse. (Opening your legs to control the animal was simply unladylike.) These attitudes had begun to shift in the late 1800s with the rise of the suffragette movement. By 1923, just three years after women had won the right to vote, Ivy Madison wrote in her book, Riding Astride for Girls: "Twenty years ago a girl who rode astride was looked on as a hoydenish creature with a shocking lack of modesty whose only reason for adopting this style must be a desire to ape masculine ways and make herself duly conspicuous."

Well, how the tides have changed: Today, an estimated 80 percent of the Western world's horse riders are women, according to a 2007 study published in Society and Animals, a journal of human-animal studies. ${ }^{1}$ Is this female prevalence because little girls dream of horses and thus more women than men grow up to ride the animals? Is there some culturally embedded link between horses and 
suffragette liberation? And if this is the case, then why? Why do young girls have such an affinity for horses? NPR posed this question in 2011, and longtime horsewoman Dominique Gioia Scaggs answered: "To be in control, or out of control, on a galloping horse is a wild feeling. ... You are one with it. You just feel the power underneath you. And that's part of the attraction."2

If you've ever ridden a horse then you might know what Scaggs is talking about. The world looks different when you're on the back of a horse-up theresurveying the scene, plotting your next move. One thousand pounds of muscle between your legs. Speeds up to 45 miles per hour. An animal that could knock you out or kill you with a single kick becomes submissive to the whims of your desire. You control the reigns, or so it feels. Go left. Right. Faster. Stop. Atta boy. If this is beginning to sound like something out of a romance novel then you're getting my intent. Horses are, at least in our history, a means to gain and express power. And power, along with all its implications - strength, authority, mastery, rule - is traditionally, culturally, associated with men. So, when you begin connecting horses, and thus ideas of power, to women, all these cultural dichotomies emerge more overtly: sexuality versus chastity; freedom versus repression; submission versus dominion.

We mythologize these polar concepts as we do ideas of masculinity and femininity. And because of our relationship with horses - down to the fact that 
we physically mount them and in so doing express our desire to control-we mythologize these animals, too. Perhaps more than any other creature on earth.

Considering all the time she spent with Bruston leading up to the auction, I assume - though never confirm - that Madison doesn't have a boyfriend. Though I imagine with her long blond hair and even longer legs she must be popular with the boys. But instead of prodding her about her romantic interests, I asked Madison about her family and what she hopes to do with her life.

"I have three older brothers and two younger sisters," she told me on a warm August day, about a month before the auction. We stood together in the corral where she trains Bruston. While we'd spoken over the phone, this was our first in-person meeting. She looked the way I imaged any teenage girl who rode horses would: braided hair, blue jeans, pink T-shirt. But she had a much more mature air about her than I expected from someone who just turned 18, which might be due to having such a big family - big brothers to learn from and little sisters to mentor. Maybe this experience and disposition make Madison the ideal candidate for gentling a wild mustang, too.

Speaking of Bruston, he was there, about five feet away, nosing a giant blue ball - the kind you might see in a gym. This proximity was tremendous progress; Madison said the last time she gently pushed the ball at Bruston he jumped and ran the 50 or so feet to the other side of the dusty corral. "He's 
sensitive," Madison explained. "And kind of a turd because he'll show off like this when other people are around."

Though that confidence bodes well for a horse that will have to show his best side to potential adopters in the coming weeks. And that's why Madison has been working on desensitizing Bruston, to get him used to, as she put it, "what life throws at him." For example, Madison strung a couple of clotheslines across the room and attached to these lines empty plastic food bags, water bottles, and egg cartons so that Bruston would be forced to touch and deal with the sounds of these objects as he rubbed against them to, say, reach his food pail. And it's paid off: Madison can now wrap her arms around the horse without so much as a flinch on his end. From all appearances, I'd say girl and horse have bonded. But maybe we just see what we want to see.

Humans have been admiring horses for at least 33,000 years. ${ }^{3}$ And I mean that in the truest sense of the word: from the Latin root admirari, "to wonder at." The oldest-known cave paintings, found in Chauvet, France, depict at least 13 animals - including bison, lions, bears, and horses. Roughly 300 miles (as the pigeon flies) to the west, in Lascaux, are the world's second-oldest-known cave paintings, dating 17,000 years. Here, according to The Cave Painters: Probing the Mysteries of the World's First Artists, "horses are the dominant animal in the cave 
and constitute over half of the one thousand or so paintings and engravings." 4 Something about these animals clearly captured the human imagination.

Still, people watched, observed and depicted (often in exquisite detail) horses for hundreds or thousands of years before interacting with them in any meaningful - or, a least, documented - way. And then what happened? We started to eat them.

Archeological evidence, including butchering tools and bones dug up in 1866, suggests the dramatic way people went about killing horses. ${ }^{5}$ If you were to journey to the southernmost foothills of Burgundy, France, for example, you would most certainly notice the Roche de Solutre, a cell-shaped mass of rock that seems to have punched through the earth. And if you were to climb up to the top of the 1600-foot ridge and face north, you'd see the acres of vineyards and, as your eyes scan down, the sparse vegetation punctuating the solid mass of bleached limestone below. Look closely, and imagine stepping back in time ten thousand years or more. Now you see them: the stacks of bones-hundreds of skeletal parts - alongside the bloodied bodies of dead or dying horses. Plenty of flesh and skin to feed and clothe your tribe.

Long before we had our stories of kings and princes and cowboys valiantly making the world better (for someone) with the aid of horses, humans must have seen horses much the same way we now view cows or pigs: as animals we kill and eat. Even after people learned how to successfully mount, 
ride and effectively control these animals, we used horses to round up other horses so that we could eat them and, eventually, raise them on our own turf as food and dairy animals. That's what probably happened at the Roche de Solutre-humans on horseback chased wild horses down the slope into a kind of archeological cul-de-sac where they (the humans) could stab and launch spears at the creatures en masse. Brutal, but effective. Especially in comparison to hunting on foot.

Archeologists aren't really sure when horses became more than food. As Horse and Human History says, "How the horse transitioned from being a food animal to its transport role ... continues to be the subject of vigorous international disputation," but in this human-horse partnership "what had once been a hostile ecological barrier to human settlement was transformed into an intercontinental corridor of rapid communication." 6

Here's what we do know: the bit, a slender piece of metal that fits snugly against a horse's molars, was invented nearly 6,000 years ago. ${ }^{7}$ The bit basically works by exerting pressure in the horse's mouth and the horse, to avoid discomfort, will follow the direction of this pressure. Horse bridles, usually made with long straps of leather that attach to bits and extend as reins, were created shortly thereafter - a combination of horse "tack" that helps people to control which way the animal goes. Right around the same time, humans invented carts and wagons and plows, making it easier to transport and harvest agricultural 
goods. And a thousand or so years after that came the first horse-drawn chariots: vehicles of war, and of the gods.

The Scythians, people of the Eurasian steppes, were the first to domesticate and use horses in this fashion. The animal's usefulness escalated it to "the cosmic animal, associated with gold, the sun and heroic warrior," according to The Horse in Human History. ${ }^{8}$ Horses could also transport souls from the land of the living to what lies beyond, which is why, as Herodotus accounted in his fourth book of History, along with a king's death, "fifty of the finest horses were killed, gutted and placed on frames" to escort the departed. ${ }^{9}$

Seems like such a waste, but I guess this practice made sense back then, and it's unlikely many people would argue with, and potentially cross, the slaying and gutting all these horses put on display. Besides, like cats to the ancient Egyptians, horses were considered so valuable and otherworldly that the gods or the universe would continue furnishing them to humanity in recompense for this kind of sacrifice. Give, and ye shall receive. Lose, so that you may gain.

Of course, the value of horses - like any animal -lies in the eye of the beholder. Consider the differing attitudes between Hittites and Israelites circa $1700 \mathrm{BCE}$, when the former, superb horse trainers and fighters, forced the latter out of Egypt. While the Hittites maintained the world's first horse-training 
manual (created around $1360 \mathrm{BCE}$ ), Jewish law forbade horse-breeding by the king. ${ }^{10}$ So while one culture celebrates, the other censures.

The perceived usefulness and, consequently, treatment of horses continued to vacillate back and forth for centuries. Back in 360 BCE, Xenophon advocated kind handling of horses in his manual, The Art of Horsemanship. ${ }^{11}$ But in the Middle Ages, Federico Grison suggested a more vicious approach in Orders of Riding. One tactic to get a horse to move on command involved trying a cat to a pole and placing the frenzied feline under the horse's belly and hind legs. ${ }^{12}$ Shortly after that, Antoine de Pluvinel decided to group horses together and choreograph them to ballet music (the first carousel), a completely frivolous display of humans' control over the animals, which inspired the Renaissanceborn sport of Dressage. ${ }^{13}$ Things got nasty yet again in the late $19^{\text {th }}$ century with inventions such as the electric bit and electric riding whip, designed to shock the animals into shape.

Even the concept of "breaking" a horse, as in breaking his spirit, informed the way people turned a young or wild horse into a tame one. This passage in an 1866 publication, "On Horse-breaking," sums up one of the most common methods:

A farmer has a colt he wishes to halter, so he gets his men together and drives he colt into a yard or stable; a man then hangs on to the timid animal by one of his ears and his nose, another seizes his tail, whilst three or four men push against either side of the poor frightened beast; then ensures a struggle: the colt, frightened out of his senses and not knowing what is 
required of him, fights the half-dozen men clinging to him; he rears, kicks, bites and strikes with his forefeet. The men on seeing this ... say he is a savage brute and must be reduced by savage means. The colt is then beaten with a broom or a pitchfork handle, his tail is twisted, and every means of inflicting excruciating pain is resorted to ... throughout all his life he is either vicious or extremely nervous and shy, for he will never forget his first introduction to mankind. ${ }^{14}$

Today, horse trainers take gentler approaches, going so far as calling the process itself "gentling" instead of "breaking." It's more of a give-and-take, pressure-and-release. You start by hanging around the horse, and then touching, then rubbing your hands along his legs, then picking up his feet, then throwing a blanket over his back. This series of activities takes a lot longer than tying the animal down to coerce submission, but people have the luxury of time now. Horses are no longer a necessity in getting from point $A$ to point $B$, or in fighting wars, or in hauling machinery and goods. These animals we once shaped our lives around have become, for the most part, novelties - from the city carriage tour to the countryside trail ride. Now impractical, a recreation, and all but gone from our daily lives, what will we do with this animal that once made so much possible? How will this story end?

Horses were born in America. The Equus ferus caballus species evolved on this continent some 55 million years ago, becoming the world's fastest distancerunning mammal before mysteriously disappearing by 4400 BCE. ${ }^{15}$ Had it not 
been for the Bering Land Bridge, or Beringia, which connected present-day Alaska with Russia, horses would never have crossed what's now a 51-mile-wide channel of ice-cold ocean. Instead, horses would be like dinosaurs: creatures we know only by way of their fossilized bones.

Blame the Ice Age for the horse's demise in its birthplace, along with the extinction of other native creatures, including American camels, wooly mammoths and saber-toothed cats. Though there is a controversial "overkill hypothesis" that suggests people basically caused this megafauna (big, heavy animals) die-off due to too much hunting. Seems unlikely, according to one article published in the Journal of Archaeological Science in 2002, which argues that "the first detailed development of the overkill hypothesis came in 1967, the same year that the Environmental Defense Fund was launched" and while the authors recognize the hypothesis originally emerged in the $19^{\text {th }}$ century, they also "suggest that the overkill argument captured the popular imagination during a time of intense concern over our species' destructive behavior toward life on earth." 16 That's not to say the argument is untrue or impossible. Humans have caused a number of extinctions over the centuries, after all. But there's no evidence proving the case; massive horse death sites, such as the one found at the base of the Roche de Solutre, simply don't exist - or have never been found -in North America. 
So, the iconic American mustang of today descends not from the world's original horse, but from a species that traveled across the Bering Sea Bridge and became tamed, domesticated, by humans in the Eurasian steppes some 5,000 years ago. By the time horses returned to America, in the sixteenth century, the people here had no idea what this animal was. Understandably, when Europeans such as Cortes arrived in South America, Amerindians fled out of fear when they saw what must have seemed, from a distance, some kind of high-speed manbeast charging after them.

This would have been a good instinct, judging from what happened over the centuries that followed. There was a particularly bloody encounter between Cortes and Aztec ruler Montezuma where, basically, Cortes enjoyed Montezuma's hospitality for a few days while trying to convert the native people to Christianity. Cortes probably realized this effort would fail when he saw the Aztecs' penchant for human sacrifice and freshly extracted human hearts sitting atop temple pyramids. So the Spaniard devised a scheme to capture Montezuma and seize control of the Aztec empire. Battles broke out. Native versus foreigner. Gallons of blood were spilled. Hundreds of people died. And, as you already know, the Spaniards - the ones with the advantage of horses - came out on top. ${ }^{17}$

Of course the story is more complicated than all that, as are the ones that followed along with the Europeans who kept coming for the gold and crops they'd never seen before - tomatoes, potatoes, squash, beans and maize, along 
with honeybees and chocolate-in effect, plundering the land while killing its people. Within 15 years of their landing in America, the Spaniards had conquered the 25 million people who' $\mathrm{d}$ been living there. ${ }^{18}$

In the process, some of the Spanish horses got away, or were abandoned. This nucleus of horses would become what's now known as the American mustang. But back then, neither of us, human or animal, knew the horses had, in a sense, returned home, to their wild state, given a second chance to thrive where nature had doomed them to extinction.

How long does something need to live here for it to be considered from here? For legislative purposes, our government basically says that something's native if it originated here (which seems to mean "lived here before European settlers arrived"), and co-evolved with other native species. Both are true, and yet not true, of horses. The species came from America, but disappeared before European settlers at last arrived. So, are horses native, or invasive?

The "native" distinction is both arbitrary and profound; it's how we decide which species to protect as opposed to which we'll (even pay to) remove. Consider another animal European settlers brought with them on their trek to America: boar. When controlled, we consider the animals useful because we eat them. But boar, like mustang, escaped into the wild centuries ago, and are now considered one of America's most reviled invasive pests. These animals also 
came by way of Spanish ships back in the 1500s but their ancestors had never been here before (as far as we know).

Because of their history, horses are biologically well-suited to the American plains. Lacking humans, wolves and bears and cougars would be horses' natural predators to keep the ecosystem in check. But humans killed these animals off en masse during the eighteenth and nineteenth centuriesaround the same time we caused the Passenger Pigeon to go extinct. Before Europeans arrived, roughly 300,000 wolves prowled this continent; by 1950, only a few hundred remained. According to a PBS Nature report, "governmentsponsored extermination had wiped out nearly all gray wolves in the lower 48 states." 19 Why? Well, simply put, wolves threatened livestock and stockowners lobbied for wolves' removal. (Even John James Audubon - the guy who inspired the National Audubon Society's creation - believed wolves "ought to be eradicated for their threat to livestock." ${ }^{20}$ ) Similarly, bounty hunting in the 1800s and 1900s brought cougar populations to the brink of extinction. And we continue encroaching on black bear territory. As a result, the BLM says, "Wild horses have virtually no natural predators." ${ }^{21}$ Except for us.

So what, exactly, are we to do? What do we owe these horses, especially if they're not even native to this country? They're actually not even wild; mustangs are feral-animals once domesticated that have since escaped and bred, for generations, outside of humans' purview. Like alley cats. 
"A wild horse consumes forage needed by domestic livestock, brings no return, and serves no useful purpose," said a grazing spokesman in $1939 .{ }^{22} \mathrm{He}$ was among many advocating government oversight over public lands - for federal laws protecting the cattle that fed America's people. Especially in tough times. Cattle ranchers would be able to lease the government's land at low-low rates and eliminate mustangs as they saw fit. This anti-horse attitude largely persisted for decades, buttressed by cattle lobbyists' claims that mustangs were "varmits" (just like wolves), non-native "foreigners" that threatened public land and water supplies.

As people did to wolves and cougars, our species killed off horses so fast that from the 1800s to the 1970s, the horse population dwindled from two million to roughly $20,000 .{ }^{23}$ In that time, horses were rounded up for trail riding, ranching, or to sell to the government during wartime. (Of the nearly 100,000 wild mustangs that served in WWI, less than a tenth returned. ${ }^{24}$ ) When meat rations became scarce, America started rounding up horses for pet food, too. A 1933 ad for Ken-L Ration dog food features the famous German shepherd Rin Tin Tin posing alongside a young boy and the headline "Horse meat is the best meat for your dog."

You could eat horse meat then, if you wanted to - in fact the Harvard Faculty Club served horse meat right up until 1985.25 With rare exceptions, though, the dietary trend never really caught on in the U.S. So resourceful 
Americans found other ways to profit off of killing horses. Portland, Oregon's Shlesser Bros., then the world's largest horse meat packing plant, slaughtered 300,000 horses between 1925 and 1930, packed them into barrels and whisked them off, by way of rail car, to New York, and subsequently Holland and Scandinavia where horse flesh remains standard human fare. "We were killing about 100 horses each day. Train loads of horses would come in once a week," said Edward Schlesser in History of Kenton. ${ }^{26}$

A woman named Velma Johnston helped stop this mass mustang killing across America. It all started the day she left work and noticed blood spilling out the back of a horse trailer. Johnston followed the trailer to a slaughterhouse and bristled at the sight: stallions with their eyes shot out, a foal (baby horse) trampled to death. She documented the treatment in a series of photos and published them, sparking public outrage. More people wrote letters urging the end of inhumane horse treatment than any other issue in U.S. history, with the exception of Vietnam. Johnston, who went by the nickname Wild Horse Annie, helped pave the way for the seminal Wild Horses and Burro Act. ${ }^{27}$

On December 17, 1971, President Nixon signed the bill and said:

Wild horses and burros merit man's protection historically--for they are a living link with the days of the conquistadors, through the heroic times of the Western Indians and the pioneers, to our own day when the tonic of wildness seems all too scarce. More than that, they merit it as a matter of ecological right--as anyone knows who has ever stood awed at the indomitable spirit and sheer energy of a mustang running free. ${ }^{28}$ 
The bill made it illegal to sell American mustangs or send them to slaughter, a major victory for horses and their advocates. Two years later, in 1973, the BLM launched its “Adopt a Living Legend" program, which gave the public a chance to "own a part of American heritage" (as it now says on its website). ${ }^{29}$ More than 230,000 mustangs and burros have been adopted through this program since.

No longer critical to our everyday life, and now more mythologized than ever, horses - and especially mustangs - are more than the animals themselves; they are symbols of the stories we tell about ourselves, about what it means to be American: rebels, outcasts, pioneers. Free spirits and risk-takers who took control of the Wild West and in so doing believed we could rule the world.

In their time together, Madison has taught Bruston how to bow and trot and turn on command. The horse even allowed her to place a blanket over his back where a human rider may someday go. But the young horse still gets the jitters. And so today, facing a crowd of some 200 people at the Yamhill County Fairgrounds, where the Teens and Wild Mustangs programs culminates in showing what these young creatures have learned to do, Madison is worried no one will want to adopt Bruston.

"I think he was feeding off of my nervousness," Madison says, echoing what I've heard from every horse trainer I've spoken to. We stand outside 
Bruston's stall after the showmanship event, wherein he failed to turn as command as he normally does and bounced his head as if he'd never learned or simply refused to do what Madison requested. I'm glad to be here, under the high-arched ceiling of an open air barn on a day when the sun makes you feel all 97 degrees of Fahrenheit. The softly sweet smell of horses permeates the space, interrupted only by wafts of grassy manure and plumes of dust. On the slab of wood, waist high, in front of me is Bruston's "baby book," photographs of Buston Madison had pasted to colored construction paper and assembled, by way of hole punch and pink ribbon. Madison is so composed when I speak to her that sometimes I forget she's so young but the book is a reminder she's still transitioning out of high school. I pick up the book and flip through, realizing Bruston has put on a bit of weight since some of these photographs were taken. He's still only a yearling and will continue to grow, reaching full size around the age of two or three when he'll be big and strong enough to carry a human around on his back.

I reach my hand between the slatted boards separating me from Bruston and try to pet his nose. He shakes his 100-pound, cowboy boot-colored head and backs off. God, I forgot how big these animals are. And mustangs are actually relatively small on the horse scale. I mean, have you ever seen one of those giant draft horses in person? I remember the first time I saw one, a Shire horse - this golden, white-footed beast sized like a mustang on steroids. The shire was 
standing in the stall at the Oregon State Fair, under a sign claiming 'Gentle Giant,' getting oogled by a flock of feverish children. I was a full-grown adult, not exactly vertically blessed but taller than the kids, and when I stretched my arm as far up and out as it could go I could just about reach the shire's jowl. I suddenly felt so small. Reminded of the trivial speck I am to the universe. (And grateful that horses are vegetarian.)

"I think that's why he didn't do so well," Madison continues. She speaks faster than on the phone or when I visited her and Bruston a few weeks ago. Her brown eyes dart around at the other horses and competitors and dozen or so people who scan the aisles and debate or decide on which horse they want to take home. In about an hour, the attendees will have a chance to bid on which of these 22 horses they want to purchase, assuming the teenagers haven't decided to keep the mustang they've worked so closely with over the last 97 days. One of them, a girl named Moira, decided she wanted to keep her horse Pippen, after all, but Pippen had already been listed for auction. So Moira set her grandparents up to bid on the horse. (And they'd later win, to the tune of $\$ 1,500$.)

Ideally, Madison would have kept Bruston. But, as a high school graduate with an eye on college and from a family of three brothers and two sisters (plus one cat and one dog), she simply didn't have the resources - the space and finances, really - to afford the option. Even taking care of Bruston during the three months she had him were tough. With the help of her parents, Madison put 
in more than $\$ 600$, but she still needed a sponsor, as many of the teens in the program do, to help buy or source enough hay and grains.

Let's put this in context of what it means to own a horse. The animal typically eats 15 to 35 pounds of food per day, which costs about five bucks. Then you have farrier costs - to trim horse hooves (so they don't get incredibly long, like fingernails or cat claws) and shoe them. Bimonthly worming runs $\$ 14$ and routine vet visits go for around \$200 annually. Add your lodging (generally $\$ 200$ and up per month) and gear, including a saddle, bit (goes in the horse's mouth), bridle (attaches to the bit to help it stay put) and reins (attach to the bridle and basically give you control), and all in, you can expect to pay roughly $\$ 8,400$ per year to own a horse. That's about how much most Americans spend on their cars every year. ${ }^{30}$ Compare that to about a grand you'd likely spend on a cat, or the two- to three-thousand you might spend on a dog in a given year. In short: owning horses ain't cheap.

Instead of keeping him, Madison hopes someone who lives close, and welcomes Madison's occasional visits, will adopt the horse she innocently and adoringly calls her "little black baby." Though mostly she just wants Bruston to get adopted, period.

A booming voice erupts over loudspeaker in the barn where Madison, Bruston and I are standing. "And now it's time to present our Teens and Oregon 
Mustang awards!" says the barn god. Madison's eyes widen and she swallows hard.

"Good luck," I say and she nods before taking Bruston out of his stall for the last time.

Madison was right in thinking she wouldn't win a scholarship that day. In fact, she placed in the bottom 10 (yes, they have an award for that). As for Bruston, a nice woman named Leslie won him for $\$ 500$ at the auction and, shortly thereafter, told Madison she's welcome to come visit the horse at his new home in Damascus any time she likes. Madison will head off to college soon, though she's still debating on her course of study: emergency services or veterinary care. She hopes to take Leslie up on her offer and come to see Bruston from time to time, maybe even ride him one day, when he's ready. But I wonder, as she moves on and life carries her away to the next destination, if she will ever see Bruston again. Or if he will become, like a childhood friend, a relic of who she once was, and what she used to believe. 
Chapter Four: A Friend in Need

"Holding this soft, small living creature in my lap this way, though, and seeing how it slept with complete trust in me, I felt a warm rush in my chest. I put my hand on the cat's chest and felt his heart beating. The pulse was faint and fast, but his heart, like mine, was ticking off the time allotted to his small body with all the restless earnestness of my own."

-Haruki Murakami, The Wind-Up Bird Chronicle

I'm in the lobby of Providence Benedictine Nursing Center, shifting my gaze between an unattended front desk and the cold rain coming down on a mostly empty parking lot. Halogen lights flicker. A draft of Band-Aids and gravy greets me from some silent place down the hall. Five minutes pass. One thought repeats: I hope no one puts me in a nursing home when I'm old. But if they do, they damn well better find a residence that allows cats.

That's the reason I've come, really. To see a man about a cat. More specifically, to meet George Piter and his feline, Maggie, who routinely visit the residents of this care center located just outside of Salem, Oregon. Piter and Maggie are taking part in what's known as Animal Assisted Therapy, a field that promotes healing through human-animal interaction. And while cats may not be the most popular choice in this work - there are 811 feline-human pairs in this country compared to 28,000 human-dog ones ${ }^{1}$ - some people seem to crave the kind of attention (or lack thereof) that only a cat can give. I want to find out why. 
Having only spoken with Piter on the phone prior to this meeting and failing to find a single photo of the man on LinkedIn, Facebook or in Google searches, I'm not sure what he looks like. But I figure-correctly - Piter will be the only person visiting today with a cat carrier in hand. Hell, he could be the only visitor of the day.

Piter steps through the sliding glass doors, bringing his cat carrier and a whoosh of the outside along with him. Normally I hate the cold but right now the crisp fall air is refreshing.

The man is of average build and height, and balding, a detail I didn't expect-I guess he sounded younger on the phone. But the rest doesn't surprise me: practical green fleece jacket, faded blue jeans, black New Balance sneakers. And don't forget the featured accessory, one buttermilk-colored animal carrier with a calico therapy cat inside.

We exchange hellos and nice-to-meet-yous and Piter lifts the carrier to just about eye-level so I can get a good look at Maggie before the grand tour. She doesn't look thrilled: crouched down, tail curled at her side, big black eyes staring right ... hmm ... what is she looking at? Ah well, all to be expected; cats are precious about their territory and can get prickly in unfamiliar situations. Take my Siamese cat, Sookie, who emits this shrill belligerent baby howl every time I take her to the vet-and for the entire 20 minutes it takes to reach the clinic. (I'm guessing Sookie isn't therapy cat material.) 
Maggie seems to warm up fairly quickly once Piter, having escorted us all down a silent hall that's now showing signs of human life, sets her down on a fold-up table near some of the staff. I see two women, or one woman and a girl, anyway. They're in a kind of cubicle with walls so short even I can see over them. The brunette middle-aged woman tells the young blonde to "go make yourself useful" at the filing cabinet, which she does, with a huff and a CLICKCLANG! Maggie takes it all in stride. She sits there, looking casual. An uneasy cat might cowl now, maybe even growl or hiss. But Maggie visits here with Piter every other week or so. That could be enough to feel like a routine, I suppose. For this place to feel like an extended part of her territory. Or maybe she's just one cool cat?

Whatever; I'm too timid to touch her. Tempted, but not gonna happen. I may have spent most of my life around cats but I don't know this particular feline and it's not like she's purring profusely, begging me to stroke her (which is generally - but not always - a sign that you may approach a feline safely). This being our first interaction, I'm not yet familiar with Maggie's nuanced body language, or mercurial shifts in attitude. We've only just met after all.

That's the thing with cats, they're pretty much the same now as they were when they came into our homes from the wild thousands of years ago: both predator and prey, felines are hardwired to shield what's truly going on lest it be perceived as weakness. Which is to say, cats can be difficult to read. A twitch of 
the tail might signify curiosity or aggravation. Interpret incorrectly and you could be on the wrong end of a nasty bite or scratch or some frenetic combination. (Seriously. You just have to see it.) With Maggie, I'd rather not take my chances.

But others will. Quite a few of them, as it turns out.

Who was the first person to have ever taken a chance on cats? The man or woman who thought it'd be a good idea to pet a wild feline, Felis silvestris lybica, and welcome the animal into his or her home, and bed? We'll probably never know, but we do have evidence that close human-cat relations date back at least 9,500 years, to the Mediterranean island of Cyprus, and likely even earlier than that.

In a 2003 excavation of the island's Neolithic town, Shillourokambos, archeologists found an ancient human skeleton buried alongside sea shells, a small green stone axe, and one eight-month-old feline. ${ }^{2}$ Since then, scientists have also found the DNA signatures of the five original cat moms (feline Eves, if you will) from which modern housecats descend. So we now know that felines came from the Near East, where present-day Turkey and Syria and Lebanon are situated. ${ }^{3}$ Cyprus is some 45 miles away from the mainland. Which means someone intentionally put cats on a boat and brought them to this island. Why? 
It all started with the vermin. Cats started coming around human settlements shortly after we invented agriculture some 10,000 years ago. People probably tolerated cats because of the animals' aid in killing the rats and mice that threatened our grain stores. But, surely, burying yourself with your cat meant you had deeper feelings that 'hey thanks for killing these rodents,' right? Seems the relationship became much more than a utilitarian one, at least on our end.

Affection grew so deep that by 3000 BCE people in the Fertile Crescent created gods in cats' image, such as Bast a.k.a. Bastet. And she was insanely popular. An annual festival in Bast's honor attracted 700,000 visitors (which is, for comparison, roughly the same number who flocked to the 2012 summer Olympics in London). Cats were clearly much more than rat catchers; they were downright sacred. Back then, in Egypt, you'd shave your eyebrows in mourning if your cat died. And anyone who killed a feline in your town would be sentenced to death. Kind of explains why some historians call this epoch the "Cult of the Cat."

Cats' territory continued to expand, despite the fact, as the UC Davis Veterinary Medicine report History of Domestic Cats and Cat Breeds suggests, "cats were jealously kept from outsiders by the Egyptians." 4 Felines wound up on the boats of Phoenician traders and sold as rat-catchers or exchanged for goods around Europe. (They'd score one cent per kitten or four pence for a full-grown 
mouser, if you were wondering.) Feline-inspired deities traveled, too, taking the shape of Artemis and Diana and Isis, black-robed goddesses of fertility and the moon and the night. $\ddagger$ People across Eurasia didn’t revere cats quite as seriously as the Egyptians, but by the turn of the millennia, cats were viewed as good luck in China, esteemed for protecting Buddhist manuscripts from manuscript-eating mice in Japan, and generally respected across Mesopotamia.

Pretty much everyone, everywhere (where cats were, anyway) recognized cats' importance. Because cats, in protecting our food supply, helped us survive.

Dale Sterling used to be an executive at an important firm before suffering a stroke some ten years ago. Today, he sits in front of me as a nursing home resident, confined to a skinny hospital bed in small, uninspiring room $\$$. Sterling can't articulate complete sentences anymore and is paralyzed from the waist down-evidenced by a pair of veiny, atrophied legs poking out of his otherwise -amply-filled hospital gown. He also has about eight teeth, which you might not notice unless Sterling is smiling, something he's doing now as Maggie is carried into the room. I follow Piter in and he places Maggie down on Sterling's bed. The

₹ Statues of Isis erected during this time often depict her holding a sistrum, a fiddle-shaped instrument that was quite popular. Could this be where "The Cat and the Fiddle" originates? Some historians think so.

$\S$ OK, seriously: does EVERY hospital, hospice and old folks' home HAVE to have the world's most depressing color palette? It's all skeleton, ash and dirt hues in here with the taupe, walls, gray countertops, laminate wood accents. Can't we have a splash of mint or sky blue or some other I'mnot-ready-to-die-yet color? 
feline circles around, once, twice, and - as if by some command or cue-curls up on Sterling's lap. Presto.

"It's amazing," Piter told me before meeting here. "What these cats do works. They read situations better than I do most of the time - and they know what they need to do."

What they need to do is this: help people heal. Not just in the literal, recovery of-cells-and-synapses kind of way. Though that's important, especially when a field like AAT wants widespread credibility. And it's proven: studies consistently show that interacting with companion animals such as dogs and cats reduces pulse rate, blood pressure, triglycerides and cholesterol. ${ }^{* *}$ These creatures are also good for your brain: petting or even looking into the eyes of your companion animal has been shown to significantly increase levels of oxytocin, a neurochemical that releases feel-good dopamine and makes us seek out social recognition and reward. (Petting a cat also releases oxytocin in her brain.) There is now so much evidence on the positive benefits of human-animal interactions that life insurance companies will weigh pet ownership in your favor.

But animals' effects on us go even deeper than all of that-in ways we can't always measure.

${ }^{* *}$ Cats, specifically, can be good for your heart. Researchers from the Minnesota Stroke Institute
discovered, over a 10 -year period monitoring 4,435 people, that the 2,235 cat owners had a 30
percent reduced risk of heart attack than non-cat-owners of the group. Cats can also help mitigate
your risk of developing asthma and allergies, provided you hung around them when you were young. 
"At a fundamental level, the benefits of pets appear to be linked to the human desire to be close to nature," states an article from the Medical Journal of Australia. ${ }^{5}$ This human desire, to be around life and life-like processes, is what scientists call biophilia. Some say we're basically born biophiliacs, that we carry this craving around in our genes. And that craving doesn't really get satisfied with all the time we spend inside these days, staring at our screens (how many hours have I logged on my computer simply writing this?), watching people on TV going outside and pretending to be lost, or in danger, so they can show us all how to stay alive. Regard: wilderness, by proxy. (Don't forget the popcorn.)

We don't get enough nature as nature probably intended. Between the park and the beach and the mountain hike, we have, in our way, all the decidedly un-lifelike things we've created - from the skyrises to the literal or digital stacks of paperwork waiting for us at the office. Our reality "really explains," wrote Sigmund Freud in a letter to a friend, "why one can love an animal ... with such an extraordinary intensity: affection without ambivalence, the simplicity of life free from the almost unbearable conflicts of civilization, the beauty of existence, complete in itself." 6

You can imagine why all these benefits would be particularly useful to people in nursing homes. Up to 90 percent of the 1.4 million people in nursing facilities exhibit depression, apathy and rapid deterioration of physical health, per a Congressional study. ${ }^{7}$ Loved ones can help soothe the symptoms, if loved 
ones are ever around. I don't mean to be such a cynic-and granted I've only been to one nursing home this one day - but it seems visitors come to Providence Benedictine about as frequently as snow sticks to the streets of Portland, Oregon. Seems the people on the outside would rather stay out there. No one wants to be reminded of what it means to grow old.

But animals don't appear to care about all that. As Alan Beck and Aaron Katcher write in their book Between Pets and People:

The animal's lack of sensitivity to the older patients' age, wrinkles, smells and debilitated condition provides a kind of social validation, a sustaining belief that their essential identity is unchanged and that in some real respect they are still what they once were. ${ }^{8}$

So that's what Maggie does: she provides something no human can.

“You see Maggie every week? You look forward to it?" I ask Sterling -in my loud voice because there's an X-Men movie blaring on the TV six feet to my left and it's the part where the Golden Gate Bridge gets blown to smithereens. Sterling nods in my direction, still grinning. He's absorbed in his movie but strokes Maggie with his right hand while his left reaches for a Big Gulp-sized thermos on the swinging bed tray hovering beside him.

I stare at Maggie and wonder how long she'll remain on Sterling's lap. She's a cat, after all, it's not like she'll listen if you tell her to Stay. (Right?) 
Piter, peering at me over his spectacles, seems to sense this. "She won't leave until she's ready," he says and proceeds to demonstrated by sliding his hands under her little body as a signal she's about to be picked up. Maggie bats at Piter's avocado-colored jacket and glares at him. Ah, a clear sign: she's not ready.

"This is the only time she shows aggression," Piter continues. "But you can see her claws don't come out. She's just letting me know it's not time yet."

So when is it time? Well, that depends. "If someone is near the end, Maggie won't let me take her away for a long while," Piter explains. A few months ago, for example, Maggie was visiting an elderly woman who was too ill to stand or even sit up. The woman's family arrived for a visit and, wanting some alone time, asked Maggie and Piter to kindly move along. "Maggie hissed at me when I tried to take her," Piter says, raising his eyebrows. "The woman died an hour later."

People who study these things have theories about the "sixth senses" many animals possess that humans have either lost-or never fully developed. As reported in The New England Journal of Medicine, Oscar the cat accurately predicted the death of 25 patients at a Rhode Island nursing home. The staff say that the feline prowls the halls daily, much like a nurse checks in on patients during routine walk-throughs. They'll know when he knows by the way Oscar saunters into a particular room, jumps on the resident's bed, and curls up next to 
him or her. Try to remove Oscar in such a situation and he'll meow in protest, caterwaul if placed on the wrong side of a closed door. ${ }^{9}$

Thoman Graves, feline expert at University of Illinois doesn't seem surprised at this behavior. "Cats can often sense when their owners are sick or when another animal is sick... They're famous for being sensitive to premonitions of earthquakes," he's quoted as saying to a BBC reporter when the Oscar case was publicized in mid-2007.10 This stance is anecdotally backed by stories similar to Oscar's, such as that of a woman named Judy Danchura who one day opened her door to a stray cat howling at 3 a.m. Danchura let the stray in and the feline followed her back to bed. The cat then jumped up beside her and proceeded to walk onto Danchura's breast. Danchura, struck by a sharp pain she'd never felt before, made an appointment with her doctor the next day. Turns out that pain was cancer, and she caught it just in time. Today she credits the cat, who she calls Sumo, with saving her life. ${ }^{11}$

Examples of this pseudo-psychic prowess aren't unique among cats. Research from the British Medical Journal, for example, describes a Labrador trained to sniff out bladder cancer. ${ }^{12}$ Then there's Lulu the potbellied pig who squeezed through the dog door, ran out into the middle of the street, and waited until someone stopped and followed the frenzied housepet back to her home, where her owner was suffering a heart attack. ${ }^{13}$ 
The science here is still anecdotal. No one knows whether an animal can truly predict Acts of God. But animals can see, smell, taste, hear and feel in ways we probably never will.

People used to believe that cats could wield supernatural powers over humans. None of the other animals we've looked at seem to possess this gift, though horses, pigs and pigeons haven't made the same kind of transition from utility to household pet. Perhaps we saw this change happening and weren't quite sure what to make of the situation. Were we being manipulated by this creature? Some called the phenomena black magic, witchcraft, evil. In the Middle Ages, cats (especially black ones) represented everything those in control wanted to eliminate: indulgence in selfish desires, refusal to obey, copulating as indiscriminately as a prostitute. So felines became associated with the most undesired of all creatures: the Devil himself.

In the thirteenth century, Archbishop Jacobus de Voragine claimed to have witnessed some of the atrocities of cat-human associations:

Some lades [sic], who had been heretics, were kneeling at Dominic's feet and suddenly cried out: "Servant of God, help us."

"Tarry a while," Dominic said, "and ye shall see what ye have been serving." Suddenly a black cat sprang up in their midst, right horrible, with long tail standing upright and emitting from the after end a terrible stench. After a while the cat climbed up the bell rope to the steeple, and the ladies were converted. ${ }^{14}$ 
People also believed that cats were the favorite animals of heretics, aka witches - especially those who believed in pagan gods such as cat-loving, blackrobed Isis, Bast reincarnate, goddess of the moon and the night. Even academic types were in on the anti-cat action. In his 1607 account of natural history, Fourfooted Beasts, Edward Topsell wrote: "The familiars of witches do most ordinarily appear in the shape of Cats, which is an argument that this beast is dangerous to the soul and body." 15

At first, the powers-that-were put all heretics on trial for their crimes, including cats. One such case tried a seven-year-old Briton tomcat for murdering his master in the year 1100 . The cat, obviously incapable of articulating his side of the story, was found guilty and sentenced to death by burning at the stake. ${ }^{16}$

Eventually citizens did away with such civility and started killing cats (and "witches") en masse. One writer calls the era the Great Cat Massacre, a time that includes spectacles such as cats set afire and carted through the streets to celebrate the coronation of Queen Elizabeth I. (Imagine the sound effects.) To honor Lent, 13 cats were placed in a cage and publically burned every year from 1344 to 1777. And to kick off the annual harvest season in Ypres, Belgium, cats were ritually thrown off rooftops. ${ }^{17}$ Belgians still indulge in this tradition, albeit the cats are now made of velveteen.

Not everyone participated in the ceremonious hatred of cats, however. Seafarers, for one, were more practical than that. Jean Baptiste Colbert, head of 
France's treasury under King Louis XIV, mandated all ships leaving France carry at least two cats to keep rodents at bay. (It was also regarded as bad luck to toss a cat overboard while at sea.) But it would take time-centuries - for anti-cat sentiments to subside. ${ }^{\dagger t},{ }^{\ddagger}$ And it would take the kind of people who saw in cats what others before could not, or refused to, appreciate.

"I don't know what it is they pick up on," Piter says as we chat about Maggie's apparent intuition. "But you can see it when you work with them." Frankly, what I see now, as I stare at Maggie there on Sterling's lap, is a cat behaving like a cat. Yeah, OK, she's calmer than some. But she still does what she wants, sits for as long as she feels like sitting, doesn't take kindly to being moved against her will. At least, that's how it appears on the surface.

Scientists are discovering there's much more than meets the eye, quite literally, when it comes to cats. We now know, for example, that cats' pupils dilate when they hear their owners' voices. This kind of pupil dilation might

\footnotetext{
t+ Even as late as 1929, people held suspicions about cats. One doctor documents a cat's murderous intent in a Nebraska State Journal article: "the family pet in the very act of suckling a child's breath, lying on the baby's breast, a paw on either side of the babe's mouth, the cat's lips pressing those of the child and the infant's pale face as that of a corpse, its lips with the blueness of death." \# So it's probably good, for cats, that no one found out until very recently that cats carry a microbe, Toxoplasma gondii, which can literally make people crazy. Rats too; Too "causes rats to become attracted to the smell of cat urine," says a 2007 New York Times report. Don't worry, it's fairly rare and indoor cats don't have it. (Usually.)
} 
signify, as the study says, "powerful emotions such as arousal or excitement." \$§

We also know that cats are more at ease around the people they're familiar with. In 2007, scientists conducted the Ainsworth Adapted Strange Situation Test on 28 cats. (This is the same test used to assess human infants' attachment to their mothers by basically seeing how much the infants freak out when their mothers leave the room.) The test showed that cats were more relaxed and confident when their owners were there with them. ${ }^{18}$

More recently, in 2010, researchers determined that people and cats often have "intense" and "complex" relationships that can require a lot of "negotiation" in terms of mutual attention and friendly physical interaction. This Behavioral Processes study also says that if a human "complies with the cat's wishes to interact, then the cat complies with the owners wishes at other times; if the owner does not comply, then neither does the cat." 19 Love me now, I'll love you later. How romantic. (Incidentally, 33 percent of cat owners do say they communicate better with their felines than with their significant others.)

Cats seduce people in other ways, too. The animals have developed a "solicitation purr" that, because of its frequency, basically makes us feel like a human baby is crying. (I'm HUNGRY! I want ATTENTION! This car ride SUCKS!) As the July 2009 edition of Current Biology explains, cats do this to

\footnotetext{
$\S \S$ Pupils dilate in humans for similar reasons, and also when we're making a decision, having an orgasm, looking at a dead body, or engaging in mentally-taxing tasks. There's a 50-second video on YouTube, Answering Questions with a Look, which captures, on film, the change in pupil size when someone tries to solve a math problem.
} 
"solicit food from their human hosts, apparently exploiting sensory biases that humans have for providing care." 20 But that's only half the story; cats' desires apparently go deeper than creature comforts. "It is unlikely that cats [actively seek human contact] just for the sake of obtaining food," says Behavioral Processes. "Cats are clearly capable of attaching socially to 'their' humans."

Maybe that's why cats have a special language, just for us. In the wild, a cat doesn't have much use for vocal communication, aside from mating and offering verbal threats. (Romantic, remember?) Even purring, often imagined as a sign of cats' content, is a means to say "stay put," or "help me out here," as a kitten does when extracting mother's milk. But cats routinely communicate with people, as if they've learned that a vocal repertoire can be quite useful in eliciting certain human behaviors.

In the 1944 study Vocalization in the House Cat: A Phoenteic and Functional Study, author Mildred Moelk documents 44 cat noises. Among them, the Begging Demand ['mrhn-a:ou:], the Complaint ['mhn-a:ou], the ['mhry] of Acknowledgement, the ['maou?] of Bewilderment. ${ }^{* * *}$ Cats chirp and trill, too, especially Maine Coon cats, the oldest breed native to North America. For example, Lexi, my Maine Coon-looking Humane Society rescue, ${ }^{\mathrm{tt \dagger}}$ uses a distinct chirrup that says to me

\footnotetext{
*** According to a 2012 study conducted by Kenton Research, 17 percent of cat owners believe, that if their cat could talk, the animal would sound like Ellen DeGeneres. Others say Fran Drescher, Sean Connery or Jay Leno sound more like it. t+t She's one of two total cats I own, complete with Sookie the Siamese; she's also undocumented so I only think she's a Maine Coon because of her big body, long hair, and the chirpy noises she makes.
} 
"Let's play with the laser!" And guess what? We do play with the laser. Lexi's chirrup is effective.

Obviously, as Cornell researcher Nicastro says, my cat “isn't forming complete sentences," 21 but she's learned how to push my buttons. And I let her. Because, in exchange, Lexi almost always comes when called, purrs contentedly as I hold her upside down, and stands on her back legs to give me a head bump when I want some feline affection. Good kitty.

Comply with the cat's wishes, so that she may comply with yours.

Cats' seeming irreverence, their I-do-what-I-want attitude, is probably why the animals came back into our domestic lives after the Great Cat Massacre. By the eighteenth century, writers such as Edgar Alan Poe and Samuel Johnson openly doted on their cats (Poe wrote "I wish I could write as mysterious as a cat"; Samuel Johnson treated his cat, Hodge, to oysters, as immortalized in a statue outside Johnson's London home). But nineteenth century France paints the perfect backdrop for cats' ultimate reemergence. Because this is when antiestablishment became kind of cool; bohemians thumbed their noses at bourgeoisie norms and revolted against social codes, instead advocating free spiritedness and individualism and imagination. Romanticism was in the air. Literature boomed. And cats seemed to fit right in. Kathleen Kete, author of Beasts in the Boudoir: Petkeeping in Nineteenth Century Paris, puts it this way: 
"Companionship of a like-minded animal became a trope of intellectuals, the cat a sign for the literary life, a signature."22

Before long cats became stars of children's books (beginning with Puss in Boots, published back in 1697), photographs (Harry Pointer specialized in capturing images of cats in baskets or on tricycles during the 1870s ${ }^{23}$ ) expos (the first official cat show at London's Crystal Palace took place on Thursday, July 13, 187124), and comic strips (such as Felix the Cat, the first image to be broadcast on TV in 192825). Cats still dominate art and popular culture to this day.

We now have internet superstar cats, such as Nyan Cat, a ridiculous cartoon feline found on YouTube. For three minutes and thirty-seven seconds, all Nyan Cat does is bounce in space, with a pixelated rainbow coming out of its rear. People apparently like it; there are more than 100 million views of this video on YouTube. Cat video runners-up, featuring actual cats, include secondplace Very Angry Cat - FUNNY (close to 85 million views) and third-place Funny Cats (almost 75 million views). Between these three videos - a tiny sampling of the available cat library - we have one billion, five hundred sixty million collective minutes of cat watching. Nearly 3,000 years, combined.

Cats are also stars of cable TV shows, such as My Cat From Hell, wherein cat whisperer (you read that right) Jackson Galaxy sets out to correct bad feline behavior. Works every time, as far as I've seen - though I suppose ratings rely on showing positive outcomes. 
Today, cats are the world's most numerous pet $-600,000$ of them live with people located around the world. ${ }^{26}$ Even though more people own dogs than cats in this country ( 46 percent versus 39 percent ${ }^{27}$ ), there are more pet cats than dogs: 86 million as opposed to 78 million. ${ }^{28}$ (Roughly as many cats as unemployed Americans, per 2011 Labor Department data.) Cats are in fact so popular today that Google X, the world's first self-learning neural network, identified cats before any other creature or object when scientists told it, in so many words, to start categorizing the universe.

Still, the question remains: why? Why are cats such a pervasive part of our culture? Why is cat-keeping a lifestyle, a preference, for hundreds of millions of people? What is it that so many of us see in these creatures?

"We delight in the cat's freedom from the constraints of civilized society," writes Katherine M. Rogers in her book The Cat and the Human Imagination..$^{29}$ I happen to agree, but this statement may not be true for all of us - there are, after all, people who don't like cats (maybe even you). Actually cat-hating, in principle, is condoned in a way that dog-hating is not; you will not find books called How to Kill Your Girlfriend's Dog or 101 Uses for a Dead Dog or How to Tell if Your Dog is Plotting to Kill You. (All real cat titles with the species' name appropriately replaced.) Seems wherever we land on the cat-liking spectrumand I think you'd tend toward affection if you'd been raised around cats - felines evoke feelings that no other animal can. 
I mean, look around. You might see a dog at the park, but that dog is always there with someone, ready to do as that person says. You might see a crow on telephone wire, squawking and cocking his head at you, if he acknowledges your presence at all. Maybe you'll spot a pigeon shuffling along the sidewalk, looking for a handout. Point is: we see these animals every day, all the time, but there's nothing quite like that cutting stare from a cat prowling at night, the Iown-this-place strut of a tomcat patrolling his neighborhood, or the la-ti-da wink of a housecat sleeping in the window, indulging in doing absolutely nothing.

Like them or not, there's something undeniably Other about cats. Something that captures our imagination in ways we're not always sure how to identify. And they've made out pretty well for themselves compared to every other animal on earth, save for dogs. Cats have managed to remain true to their nature while adapting just enough to the way we live and what we desire.

Maggie is ready to leave Sterling's lap. I can tell when Piter goes to pick her up, and she readily concedes. No hisses or bats to the hand; it's time to move on.

Piter leads me out of Sterling's room into the low, particle-board-ceilinged hall, which then opens up in a kind of common area, roughly the size of a kindergarten classroom. He situates me near a few of the residents and says he needs to go find a towel so he can create what he calls a "Maggie burrito" for the next visitor. Don't leave me here alone, I think. But I say nothing and pretend I'm 
fine standing next to this heavy-set woman in a wheelchair who has a foam donut around her neck. She wears Barbie pink, which seems a kind of travesty, and I wonder if she had a say in the wardrobe selection. Next to her, at an otherwise empty card table, a silver-haired woman in royal blue stares out the tall window overlooking the parking lot. I follow her gaze into the gray sky pressing down on a handful of Toyotas and Hondas. "I'm from San Francisco," she says, with a lilt, to no one. "I wish I could go back to San Francisco."

I look down at my feet and try to muster some conversation. But really, I have no earthly idea how to reply. I mean, what the hell do you say to this stranger, to this elderly woman you don't know and will probably never see again? I'm sure she used to be young and beautiful and loved but now sits in an old folks' home, lamenting to the air, because the people close to her are unable or unwilling to care for her. I could be her one day. I mean, I don't have children, but if I did - and if grew elderly and infirm - my offspring could decide to stick me in a nursing home with a bunch of other old, forgotten people.

Gah.

Where the hell is Piter? Or someone who works here? Anyone?

Enough; I can't stand the silence.

"I bet it's sunny in San Francisco," I say. What a putz. I mean, really, that couldn't have been a stupider response. Just called out one more thing this 
woman has lost and can't ever get back. But she doesn't seem to mind. Rather, she doesn't react at all. Did she hear me? Does she ever hear anyone? Is there even anyone left worth listening to?

Piter doesn't return soon enough but when he does, he's equipped with a petite white bath towel that's wrapped around Maggie so that only her little black-and-white-and-brown head pokes out. The cat's expression is exactly the same as when we arrived. On guard, surely focused on something in another dimension, but not agitated. I'm betting if I made a burrito out of my Siamese Sookie she'd, well, let's just say she would clearly vocalize her displeasure.

Piter introduces me to Alice, our next visitor. I spin around and say hello to Alice, who is also in a wheelchair but, unlike the woman from San Francisco, has a giant (and maniacal) smile on her face. She aims her smile at me, blinking profusely.

“DO YOU WANT TO SEE MAGGIE?” Piter asks Alice. Now he's using his loud voice. “MAGGIE THE CAT? YOU REMEMBER MAGGIE?"

"I will," Alice sings.

Down goes the Maggie burrito onto Alice's blue-and-purple muumuu. An old man wheels up to us - where'd he come from? - and grunts at me, says "Excuse me" so I move out of his way. He takes a look back when he reaches a second card table a few feet away from us. "That's a pretty kitty," he mumbles. 
"Why thank you!" Alice replies as she strokes the cat (burrito). The woman seems to have high spirits and I wonder if she's always like this or if she lights up when Maggie's around. Piter nods at me, a suggestion that we step aside-out of earshot. (About two feet away.) He tells me, softly, that Alice has advanced multiple sclerosis and can't really control her limbs that well. Ah, that's why the Maggie burrito-wrap up the feline to restrict her movement justincase she uncharacteristically lashes out in fear when startled. As I'm thinking this Alice's hand inadvertently smacks Maggie in the face. The cat appears unfazed. (This is when most cats, including Sookie, are likely to slap you back or take off with an I-don't-need-this-shit swagger.) Alice continues petting; Maggie continues to let her.

"We go through rigorous training," Piter explains with a kind of shrug. He had detailed this for me a few days ago over the phone. To become a certified cat-human AAT partnership, would-be therapy animals are placed in what might be considered high-stress situations. For cats, this involves being placed in an auditorium where staff and volunteers throw pizza pans onto the floors, scream at each other, and bang walking sticks against haphazardly-placed chairs with metal legs. A cat "passes" this stress test if it willingly stays in one place for a defined period of time (about 30 seconds, which is roughly an eternity in the land of cat attention span), and shows no signs of lashing out at the rowdy. 
This process is really what makes a therapy cat a therapy cat. As Jennifer Moody, development coordinator of the Oregon Chapter of Pet Partners, told me over the phone, "A companion animal, or a pet, is a personal animal. A therapy animal is used by volunteers in hospitals or assisted living facilities. They go through special requirements." And they have the right personality for the job. (Yes, if you're wondering, there have also been studies on cat personalities - as well as other animals, such as horses. Researchers typically rank the animals according to "the big five" personality traits: extraversion, agreeableness, conscientiousness, neuroticism and openness. The same kind of research also ranks people who own pets; dog owners are usually more sociable, selfdisciplined and traditional whereas cat people are generally more neurotic, spontaneous and open to new experiences.)

So why choose cats, specifically?

For Piter, it was an unmet need.

After retiring from the Air Force, Piter decided to volunteer time to places like Providence Benedctine and the Salem Hospital. He started as an IT consultant, his area of expertise for 25 years, before the idea struck.

“Some people would bring dogs to interact [with Providence residents] but I noticed a lot of the residents had pictures of cats all over their rooms," he told me during our initial phone conversation. "I thought it might be fun to bring Maggie in. And she was an instant hit, she immediately connected with people." 
Maggie had immediately connected with Piter, too, when she followed him home 13 years ago and never left. He hadn't owned a cat before, nor thought about owning one. But when she came into his world Piter's attitude about cats, along with his trajectory in life, took what he calls a "complete 180." Today, Piter is the proud owner of Maggie and four other felines.

Cats can have that effect on people. They can enter your life at the right time and imprint something difficult to name and yet impossible to remove. They dig in deep, and even when they're gone the claws never come out. Let me try to explain.

My first cat - and I mean the first one I ever had any responsibility for showed up outside my bedroom window on my ninth birthday. I was pretty sure this was a gift from the universe. And I'm still pretty sure I was born an animal lover (extreme biophliac?) but my father and I had been living without a pet for two years, ever since my parents split. He and I had moved from California to Hawaii while my mother went back to her native Canada, half a world away. It was a confusing time. Maybe that's why my dad let me keep C-A$\mathrm{T}$.

I loved this cat like nothing else. I loved the way she curled up on my lap as I read, and snuggled on the couch during the Wonder Years and Doogie Howser, M.D., and came back home every time I called. I even loved when she gave birth 
to a litter of kittens on my bed and left a Rorschach-like bloodstain in my sheets that never washed out.

C-A-T gave birth twice, in fact. The first happened in the VW camper van we could never completely keep closed. I'd been following C-A-T closely since I noticed her growing belly. So I was there with her the day she jumped into the van and, with a bewildered look, began having contractions. Six kittens came out, along with some blood and placenta, which C-A-T promptly ate up. I learned from this cat what no sex education class ever could.

But I hadn't yet learned what can happen to a cat when you let her roam free-susceptible to automobiles and disease-and never take her to the vet. I also hadn't yet learned that feral cats are a big problem in Hawaii. (Other places too; un-owned cats kill at least a billion birds annually. And a single cat is thought to have brought an entire population of Stephen Island Wrens to extinction in the late $1800 \mathrm{~s} .{ }^{30}$ ) So, when no one took any free kittens from the box I'd bring to the local market, I'd just go home, and let the baby cats roam free outside my house. One by one, like a twisted children's nursery rhyme, the kittens disappeared. After a while, C-A-T stopped coming home, too. I eventually realized she never would.

Some cats keep coming back long after their owners stop calling. In a small Italian village just north of Florence, there's a cat named Toldo who continually 
returns to his owner, Renzo, long after the man's death. Except, the cat's not going home. Instead, he visits Renzo's tombstone, nearly every day (and sometimes twice). Local residents think Toldo must have followed Renzo's coffin on its journey to the burial grounds some two years ago. But no one knows why Toldo keeps going back. Or why, along the way, he picks up twigs or toothpicks or acacia sprigs - small objects he can carry in his mouth - sets them down on Renzo's grave, and just sits there for a while, like the Sphinx. If you ask me, it seems like Toldo is looking for something he's lost. Something that was important to him.

What do animals think, if anything, of death? If a cat can detect when we're on our deathbed, what's the significance of this finding to the feline? And what happens to us, in a cat's mind, when we die?

People who study human and animal behavior call it anthropomorphizing when we ascribe human traits - such as mourning and happiness - to animals. And we've seen how this practice doesn't work out. Take, for example, the night of October 3, 2003 when Montecore the tiger got clamped his jaws around the throat of his trainer, Roy Horn (of Siegfreid and Roy), and dragged the man thirty feet offstage mid-performance. Horn had worked with tiger for seven years, since Montecore was a cub. ${ }^{31}$ No one saw this coming. Then there's $40-$ year-old SeaWorld Orlando trainer Dawn Brancheau who was drowned by a 
Killer Whale named Tilikim, just minutes after the interactive human-animal show "Dinner with Shamu." 32

Point being, animals are still animals. Instincts can be unpredictable. We never really know what goes on in an animal's head or what the creature might do to us, on a whim, in a down mood. We can't pretend to know how it feelsjust as we can't pretend to know what other people feel, or how they'll react in new or uncomfortable situations.

But we still do. We all make judgments based on things both seen and unseen because-after millennia identifying, codifying and telling stories about the things we believe-it's how we've learned to survive.

Piter tells me we're going to Providence Benedictine's psych ward. And I'll admit: as we walk down the long hall that leads to a passcode-protected door, scenes from The Shining pop in my head, including the one where the kid creaks down an empty hall on his tricycle until two undead twins accost him. And the one where Jack Nicholson finally loses it and chases after his wife with an axe. I've never been to a psychiatric ward. My imagination fills in the blanks.

Piter enters the passcode and opens the door to a quiet, gray environment humming with halogens. The light is bluer in here than the yellow tint in the rest of the facility. I look around the open space, about half the size of an Olympic swimming pool and completely lacking in individual rooms like the one Sterling 
had. There are about 15 people in here, all sitting, most of them in wheelchairs. A redheaded woman in scrubs - an employee-smiles and winks and Piter and Maggie. The two are a welcome sight.

I follow Piter as he approaches, slower than before, the people peppered around the room. A man with nubs for limbs is first. Something about him, maybe the buzzcutt, tells me he's a veteran. I wonder how long he has lived like this. Does he remember what it's like to walk around, comb his hair, drink a beer? Does he miss driving with the windows down, embracing a woman, stretching his limbs outside on a warm summer day? We take so much for granted.

Maggie won't be set on this man's lap but Piter bends over to put her within reach and the man caresses Maggie with what's left of his left arm.

Another elderly gentleman in a rocking chair sits nearby. Piter approaches and asks "Do you want to pet Maggie?"

The man furrows his salt-and-pepper brows together, plants his sneakers into the floor, and heaves his chair back with all his might. He's breathing heavier now, eyeing the three of us as if we've seriously offended him and are capable of much worse.

Which begs the question: what happens when people want nothing to do with Maggie? If a person is allergic, or ailurophobic (afraid of cats) or simply despises felines? 
"Generally we visit people we know, people who request to see Maggie," Piter had told me. “With new people, we'll just ask. If they don't like cats, or are allergic, we'1l just move along."

I suppose there's not much a resident can do if she or he doesn't want to see a cat. Many of the folks in here can't speak and even if they did complain, I think most everyone would agree there seems to be more good coming out of the interactions with Maggie than potential bad; most of the Providence Benedictine residents seem happy to have the company.

A woman, with a bright red wig, spots Maggie from across the room. “THAT cat! THAT cat!" she yells. "I've seen THAT cat before!"

Piter beelines toward her, and I follow. Piter leans in to let the woman pet Maggie, which she does. "I'll feed her and I'll pay all her vet bills for you," the woman says excitedly. "I'1l take her home!"

Of course, she never will. I think of her family, of the person who had to decide it was time to put this woman in here, to find somewhere psychiatrists and care providers could attend to her special needs. An impossible choice, as it seems to me now. As Piter says “It's not an easy place-these aren't easy places to be, but the people here do a good job." And here, just like everywhere, people do what they can to survive and to be comfortable and to find fulfillment. Sometimes, for some of us, we find solace in a small, half-tame, half-wild animal 
that trusts us enough to curl up on our lap, and in so doing reminds us of something or someone we once had, or always wanted, or never really knew.

Piter nods at me, a signal it's time to leave. Neither Maggie nor the woman seem to know exactly what's going on but I know they'll both adapt to the change. I follow the man and cat back out to the windowed-lobby and notice the rain has stopped, for now. I thank Piter and, without even thinking about it, give Maggie a pat on the head, and say goodbye. 
Notes and Bibliography

Chapter One: Feeding the Beast

${ }^{1}$ Lunde, Katherine. "Genetic Variation of an Odorant Receptor OR7D4 and Sensory Perception of Cooked Meat Containing Androstenone," PLoS ONE, 7, no. 5 (2012): 1 , http://www.plosone.org/article/info:doi/10.1371/journal.pone.0035259 (accessed June 12, 2013).

2 Meindertsma, Christine. Pig 05049. Rotterdam: Flocks, 2007.

${ }^{3}$ Eng, Monica. "The Costs of Cheap Meat." Chicago Tribune, sec. Feature, September 24, 2010. http:/ / articles.chicagotribune.com/2010-09-24/health/ctmet-cheap-protein--20100923_1_factory-farms-cafos-salmonella-outbreak (accessed July 12, 2013).

${ }^{4}$ American Meat Institute, "United State Meat Industry at a Glance." Last modified 2013. Accessed June 14, 2013.

http://www.meatami.com/ht/d/sp/i/47465/pid/47465.

${ }^{5}$ Ibid.

6 U.S. Department of Agriculture, National Agricultural Statistics Service "Livestock Slaughter 2011 Summary (April 2012)" http://www.thefarmsite.com/reports/contents/liveanapril12.pdf (accessed August 12, 2012).

7 Philpott, Tom. "If JBS gobbles up Smithfield, three companies will own U.S. meat market." Grist, sec. Food, June 30, 2010. http://grist.org/article/foodwall-street-bets-on-jbs-takeover-of-pork-giant-smithfield/ (accessed June 21, 2012).

8 Burrows, Edwin G, and Mike Wallace. Gotham: A History of New York City to 1898. New York: Oxford University Press, 1999.

9 The National Pork Board, "The History of Pork." Last modified 2013. Accessed April 19, 2012. http://www.porkbeinspired.com/about_thehistoryofpork.aspx.

${ }^{10}$ Starmer, Elanor, and Wise, Timothy A. Living High on the Hog: Factory Farms, Federal Policy, and the Structural Transformation of Swine Production. Working paper. Tufts University, 2007. Global Development and Environment Institute http://www.ase.tufts.edu/gdae/Pubs/wp/0704LivingHighOnHog.pdf.

${ }^{11}$ Smithfield Foods, "Many Names, One Family (Company History)." Last modified 2013. Accessed February 12, 2013. 
http://www.smithfieldfoods.com/our-company/family-of-companies/hogproduction/murphy-brown/.

${ }^{12}$ Starmer and Wise, Living High on the Hog.

13 Tiez, Jeff, and . "Boss Hog: The Dark Side of America's Top Pork Producer." Rolling Stone, December 14, 2006.

http://www.rollingstone.com/culture/news/boss-hog-the-dark-side-ofamericas-top-pork-producer-20061214 (accessed April 2, 2012).

${ }^{14}$ National Hog Farmer , "Smithfield Responds to Rolling Stone Article." Last modified January 9, 2007. Accessed May 2, 2012. http://nationalhogfarmer.com/news/smithfield_responds_rolling_stone.

${ }^{15}$ Oppel Jr., Richard. "Videos Show Cruelty on Farm, And Taping Becomes the Crime.." New York Times, April 7, 2013. http://www.nytimes.com/2013/04/07/us/taping-of-farm-cruelty-is-becomingthe-crime.html?_r=0 (accessed August 13, 2013).

${ }^{16}$ Humane Society of the United States, "Scientists and Experts on Gestation Crates and Sow Welfare." Last modified October 2012. Accessed November 21, 2012. http://www.hum

${ }^{17}$ Strom, Stephanie. "McDonald's Set to Phase Out Suppliers' Use of Sow Crates." New York Times, February 13, 2012. http://www.nytimes.com/2012/02/14/business/mcdonalds-vows-to-help-enduse-of-sow-crates.html (accessed March 13, 2012).

18 "Pass notes, No 2,956: Crash test dummies." The Guardian, April 10, 2011. http://www.theguardian.com/technology/2011/apr/10/crash-test-dummiesobesity (accessed February 8, 2012).

${ }^{19}$ Greenemeier, Larry. "Pigs Could Be the Salvation of Diabetes Sufferers." Scientific American, January 31, 2008.

${ }^{20}$ Nosowitz, Dan. "Japanese Scientist May Have To Grow His Human Organs In American Pigs." Popular Science, June 20, 2013. http://www.popsci.com/science/article/2013-06/japanese-scientist-may-havemake-his-human-pig-organs-america (accessed July 20, 2013).

${ }^{21}$ United States Department of Agriculture, Animal and Plant Health Inspection Service, "Feed Management of Swine." September 2002. http://www.aphis.usda.gov/animal_health/nahms/swine/downloads/swine2 000/Swine2000_is_FeedMgmt.pdf (accessed July 22, 2012).

22 "National Survey: Green is Officially Mainstream - But Consumers are Confused, Skeptical About Products." Shelton Group. press release, June 29, 2009 on the Shelton Group website, http://www.sheltongroupinc.com/press/ecopulse/press_releases/EcoPulseNe wsReleaseNaturalvOrganic.pdf (accessed June 23, 2012). 
Chapter Two: Letting Go

${ }^{1}$ Blechman, Andrew. Pigeons: The Fascinating Saga of the World's Most Revered and Reviled Bird. New York: Grove Press, 2006.

2 Ibid.

${ }^{3}$ Yapp, Robin. "Colombian police capture pigeon carrying drugs to prison." The Telegraph, January 19, 2011.

http://www.telegraph.co.uk/news/worldnews/southamerica/brazil/8269366/ Colombian-police-capture-pigeon-carrying-drugs-to-prison.html (accessed September 20, 2013).

${ }^{4}$ Freedman, Roy. Introduction to Financial Technology. Burlington: Elsevier, 2006.

5 Thomson Reuters, "Company History." Accessed August 22, 2012. http://thomsonreuters.com/about-us/company-history/.

${ }^{6}$ Humphries, Courtney. Superdove: How the Piegon Took Manhattan and the World. New York: Harper Collins, 2008.

${ }^{7}$ pigeons received 32 Dickin Medals for their wartime service

8 "Spy pigeon's medal fetches £9,200." BBC News, November 30, 2004. http://news.bbc.co.uk/2/hi/uk_news/4054421.stm (accessed October 8, 2012).

9 Pigeons in Combat, "The Pigeoneers." Accessed September 1, 2013. http://www.pigeonsincombat.com/thepigeoneerswebpage.html.

${ }_{10}$ Moore, Malcom. "China trains army of messenger pigeons."The Telegraph, March 2, 2011. http://www.telegraph.co.uk/news/worldnews/asia/china/8356921/Chinatrains-army-of-messenger-pigeons.html (accessed April 4, 2012).

${ }^{11}$ Dillow, Clay. "How Homing Pigeons Find Their Way Home." Popular Science, February 1, 2013. http://www.popsci.com/science/article/201301/geologist-has-probably-figured-out-how-homing-pigeons-find-their-wayhome (accessed May 12, 2013).

12 Ibid.

${ }^{13}$ Cardinal, C.D., Allan, R.W., \& DeLabar, J.S. "Self-awareness in the pigeon: A replication and controls." Association for Behavior Analysis Abstracts, Chicago, Illinois, 1999.

14 Ibid.

${ }^{15}$ Muir, John. The Story of My Boyhood and Youth. New York: Houghton Mifflin Company, 1913.

16 Ibid.

${ }^{17}$ Loomis, Bill. "Slaughtered to extinction: Passenger pigeons in Michigan." The Detroit News, March 18, 2012. 
http://www.detroitnews.com/article/20120318/METRO/203180301 (accessed July 1, 2012).

${ }^{18}$ Audubon, John James. The Birds of America from Drawings Made in the United States and Their Territories. New York: V.G. Audubon, 1836.

19 "Passenger Pigeons." The Roosevelt Center at Dickinson University (blog), http://www.theodorerooseveltcenter.org/Blog/2013/August/09-PassengerPigeons.aspx (accessed January 23, 2013).

${ }^{20}$ Stromberg, Joseph. "Martha, The World's Last Passenger Pigeon." Smithsonian (blog), September 1, 2011. http://blogs.smithsonianmag.com/aroundthemall/2011/09/martha-theworlds-last-passenger-pigeon/ (accessed September 9, 2012).

${ }^{21}$ Leopold, Aldo. A Sand County Almanac, and Sketches Here and There. New York: Oxford University Press, 1949.

Chapter Three: (Losing) Control

${ }^{1}$ Midkiff, Mary D. Fitness, Performance and the Female Equestrian. New York: Howell Book House, 1996.

2 Kitchen Sisters, . "Why Do Girls Love Horses, Unicorns And Dolphins?." NPR, February 9, 2011. http://www.npr.org/2011/02/09/133600424/why-do-girls-love-horsesunicorns-and-dolphins (accessed September 30, 2013).

${ }^{3}$ Kelekna, Pita. The Horse in Human History. New York: Cambridge University Press, 2009.

${ }^{4}$ Curtis, Gregory. The Cave Painters: Probing the Mysteries of the World's First Artists. "New York: First Anchor Books, 2007.

${ }^{5}$ Archeological evidence, including butchering tools and bones dug up in 1866 ,

${ }^{6}$ Kelekna, Pita. The Horse in Human History.

7 Ibid.

8 Ibid.

${ }^{9}$ Ibid.

${ }^{10}$ Hughes, Bettany. Helen of Troy: The Story of the Most Beautiful Woman in the World. New York: Vintage Books, 2007.

${ }^{11}$ Xenophon, The Art of Horsemanship. Dover Publications, 2006.

12 The Works of Chivalry, "Coats, socks, blazes and the theory of humors." Accessed August 19, 2013. http://worksofchivalry.com/en/tag/federicogrisone/. 
${ }^{13}$ Stillman, Deanne. Mustang: The Sage of the Wild Horse in the American West. Boston: Mariner Books, 2008. 1877.

${ }^{14}$ Moreton, Robert. On Horse-Breaking. London: Longmans, Green and Co.,

${ }^{15}$ American Museum of Natural History , "The Evolution of Horses." Accessed April 24, 2012. https://www.google.com/search?q=horses evolved north america \&oq=horses evolved north america \&aqs $=$ chrome..69i57j0.4550j0j4\&sourceid=chrome\&espv=210\&es_sm=91\&ie=UT F-8.

${ }^{16}$ Grayson, Donald, and David Meltzer. "A requiem for North American overkill." The Journal of Archeological Science. (2002): 585-593. http://faculty.washington.edu/grayson/jas30req.pdf (accessed August 18, 2013).

17 Stillman, Deanne. Mustang.

18 Ibid

${ }^{19}$ PBS Nature, "The Wolf That Changed America." Accessed July 9, 2013. http://www.pbs.org/wnet/nature/episodes/the-wolf-that-changedamerica/wolf-wars-americas-campaign-to-eradicate-the-wolf/4312/.

20 Ibid.

${ }^{21}$ Gorey, Tom. BLM, "Wild Horse and Burro Quick Facts." Last modified July 25, 2011. Accessed September 18, 2013. http://www.blm.gov/wo/st/en/prog/whbprogram/history_and_facts/quick_ facts.html.

${ }^{22}$ Roth, Melinda. Mestengo: A Wild Mustang, A Writer on the Run and the Power of the Unexpected. Guilford: Lyons Press, 2013.

${ }^{23}$ Johnston, Charlie. "Wild Horses." Nevada Magazine, January 2009. http://nevadamagazine.com/issues/read/wild_horses/ (accessed September 4, 2013).

${ }^{24}$ Stillman, Deanna. Mustang.

${ }^{25}$ Burnham, Ted. "Plan To Slaughter Horses For Human Consumption Is Met With Distaste." NPR, April 28, 2012. http://www.npr.org/blogs/thesalt/2012/04/17/150833468/plan-to-slaughterhorses-for-human-consumption-is-met-with-distaste (accessed September 29, 2013).

26 "Oral History: Edward Schlesser. History of Kenton." 135-138. Courtesy of the Kenton Neighborhood Association. 2013.

http://ccrh.org/comm/slough/oral/schlesser.php (accessed July 1, 2013).

27 Stillman, Deanna. Mustang. 
${ }^{28}$ Cohen, Andrew. "Think Our Wild Horses Are Safe?." The Atlantic , December 16, 2011.

http://www.theatlantic.com/national/archive/2011/12/think-our-wild-horsesare-safe/250062/ (accessed July 1. 2013).

${ }^{29}$ BLM, "Adoption Program." Accessed August 8, 2013.

http://www.blm.gov/wo/st/en/prog/whbprogram/adoption_program.html. 30 "Your 2012 Driving Costs ." AAA, April 2012.

Chapter Four: A Friend in Need

1 Zeiner, Lisa. Email to Jocelyn Brady, February 15, 2012.

2 Rincon, Paul. "Dig discovery is oldest 'pet cat'." BBC News, April 8, 2004. http://news.bbc.co.uk/2/hi/sci/tech/3611453.stm (accessed April 13, 2013).

${ }^{3}$ Ibid.

${ }^{4}$ Wastlhuber, J. History of Domestic Cats and Cat Breeds. manuscript., UC Davis, 2007. Australia.

${ }^{5}$ Headey, Bruce. "Pet Ownership: Good for health?."Medical Journal of

6 Blazina, Christopher, Guler Boyraz, and David Shen-Miller. The Psychology of the Human-Animal Bond. New York: Springer Science Business Media, 2011.

${ }^{7}$ Chicago Bridge, "Paws and Claws: Pets as Medicine." Last modified November 11, 2012. Accessed August 19, 2013. http://www.thechicagobridge.org/paws-and-claws-pets-as-medicine/.

${ }^{8}$ Beck, Alan and Katcher, Aaron. Between Pets and People: The Importance of Animal Companionship. Purdue University Press, 1996.

9 "US cat 'predicts patient deaths'." BBC News, July 26, 2007.

http://news.bbc.co.uk/2/hi/americas/6917113.stm (accessed May 17, 2012).

${ }^{10} \mathrm{Ibid}$.

11 "Stray cat credited in cancer diagnosis." CBC News, March 1, 2010. http://www.cbc.ca/news/canada/manitoba/stray-cat-credited-in-cancerdiagnosis-1.962453 (accessed August 9, 2012).

12 "Dog trained to smell skin cancer." BBC News, May 5, 2005.

http://news.bbc.co.uk/2/hi/uk_news/england/4515651.stm (accessed November 1, 2011).

${ }^{13}$ Moussaieff Masson, Jeffrey. The Pig Who Sang to the Moon. Random House, 2003. 
14 Thornsett, Michael C. Heresy in the Roman Catholic Church: A History.

North Carolina: McFarland \& Company, Inc., 2011.

${ }^{15}$ Topsell, Edward, The History of Four-footed Beasts and Serpents, London: E.Cotes for G. Sawbridge, 1658.

${ }^{16}$ Darnton, Robert. The Great Cat Massacre: And Other Episodes in French

Cultural History. New York: First Vintage Books, 1984.

17 Ibid.

18 Wedl, Manuela, Barbara Bauer, and Dorothy Gracey. "Factors

influencing the temporal patterns of dyadic behaviours and interactions between domestic cats and their owners." Behavioral Processes. (2011): 58-67.

http://medienportal.univie.ac.at/uploads/tx_ttmedienportal/files/Wedl_et_al. _2010_Behavioural_Processes.pdf (accessed November 21, 2012).

19 Ibid.

${ }^{20}$ McComb, Karen, Anna Taylor, and Christian Wilson. "The cry embedded within the purr." Current Biology. no. 13 (2009): 507-508.

${ }^{21}$ Segelken, Roger. "It's the cat's meow: Not language, strictly speaking, but close enough to skillfully manage humans, communication study shows." Cornell Chronicle, May 20, 2002.

http://www.news.cornell.edu/stories/2002/05/meow-isnt-language-enoughmanage-humans (accessed July 9, 2012).

${ }^{22}$ Kete, Kathleen. The Beast in the Boudoir: Petkeeping in Nineteenth Century Paris. California: The University of California Press, 1994.

${ }^{23}$ Sussex PhotoHistory , "Harry Pointer's Brighton Cats." Accessed April 1 2012. http://www.photohistory-sussex.co.uk/BTNPointerCats.htm.

${ }^{24}$ Kete, Kathlene. The Beast in the Boudoir.

${ }^{25}$ Felix The Cat: History of Felix, "Electronic TV Broadcasts Began in 1928 with Felix!." Accessed APril 19, 2013. http://www.felixthecat.com/history.htm.

${ }^{26}$ Carlos, Driscoll, ,et al. "The Evolution of House Cats."Scientific American, June 10, 2009. http:/ / www.scientificamerican.com/article.cfm?id=the-taming-ofthe-cat (accessed June 9, 2012).

27 The Humane Society of the United States, "Pets by the Numbers." Last modified September 17, 2013. Accessed September 30, 2013. http://www.humanesociety.org/issues/pet_overpopulation/facts/pet_owners hip_statistics.html.

${ }^{28}$ Ibid.

${ }^{29}$ Rogers, Katherine M. The Cat and the Human Imagination. Detroit: The University of Michigan Press, 1998.

30 "Cats Kill Billions; 15 Percent Of Bird Population Destroyed Each Year." International Science Times, January 29, 2013. 
http://www.isciencetimes.com/articles/4446/20130129/cats-kill-billions-15percent-bird-population.htm (accessed June 29, 2013).

${ }^{31}$ Leach, Robin. "Revelations from Siegfried \& Roy as 10th anniversary of tiger Montecore incident approaches." Las Vegas Sun, September 30, 2013. http://www.lasvegassun.com/vegasdeluxe/2013/sep/30/siegfried-royrevelations-10th-anniversary-tiger-i/ (accessed September 30, 2013).

32 Kennedy, Helen. "Killer whale kills trainer at Orlando's Sea World; whale Tilikum linked to two other human deaths." New York Daily News, February 10, 2010. http://www.nydailynews.com/news/national/killer-whalekills-trainer-orlando-sea-world-whale-tilikum-linked-human-deaths-article1.168269 (accessed August 29, 2013). 